\title{
Removal of heavy metals and pollutants by membrane adsorption techniques
}

\author{
K. C. Khulbe ${ }^{1} \cdot$ T. Matsuura $^{1}$
}

Received: 17 May 2017 / Accepted: 27 December 2017 / Published online: 24 January 2018

(c) The Author(s) 2018. This article is an open access publication

\begin{abstract}
Application of polymeric membranes for the adsorption of hazardous pollutants may lead to the development of next-generation reusable and portable water purification appliances. Membranes for membrane adsorption (MA) have the dual function of membrane filtration and adsorption to be very effective to remove trace amounts of pollutants such as cationic heavy metals, anionic phosphates and nitrates. In this review article, recent progresses in the development of MA membranes are surveyed. In addition, recent progresses in the development of advanced adsorbents such as nanoparticles are summarized, since they are potentially useful as fillers in the host membrane to enhance its performance. The future directions of R\&D in this field are also shown in the conclusion section.
\end{abstract}

Keywords Adsorption $\cdot$ Graphene $\cdot$ Water treatment $\cdot$ Carbon nanotubes $\cdot$ Membrane $\cdot$ Wastewater $\cdot$ Zeolites

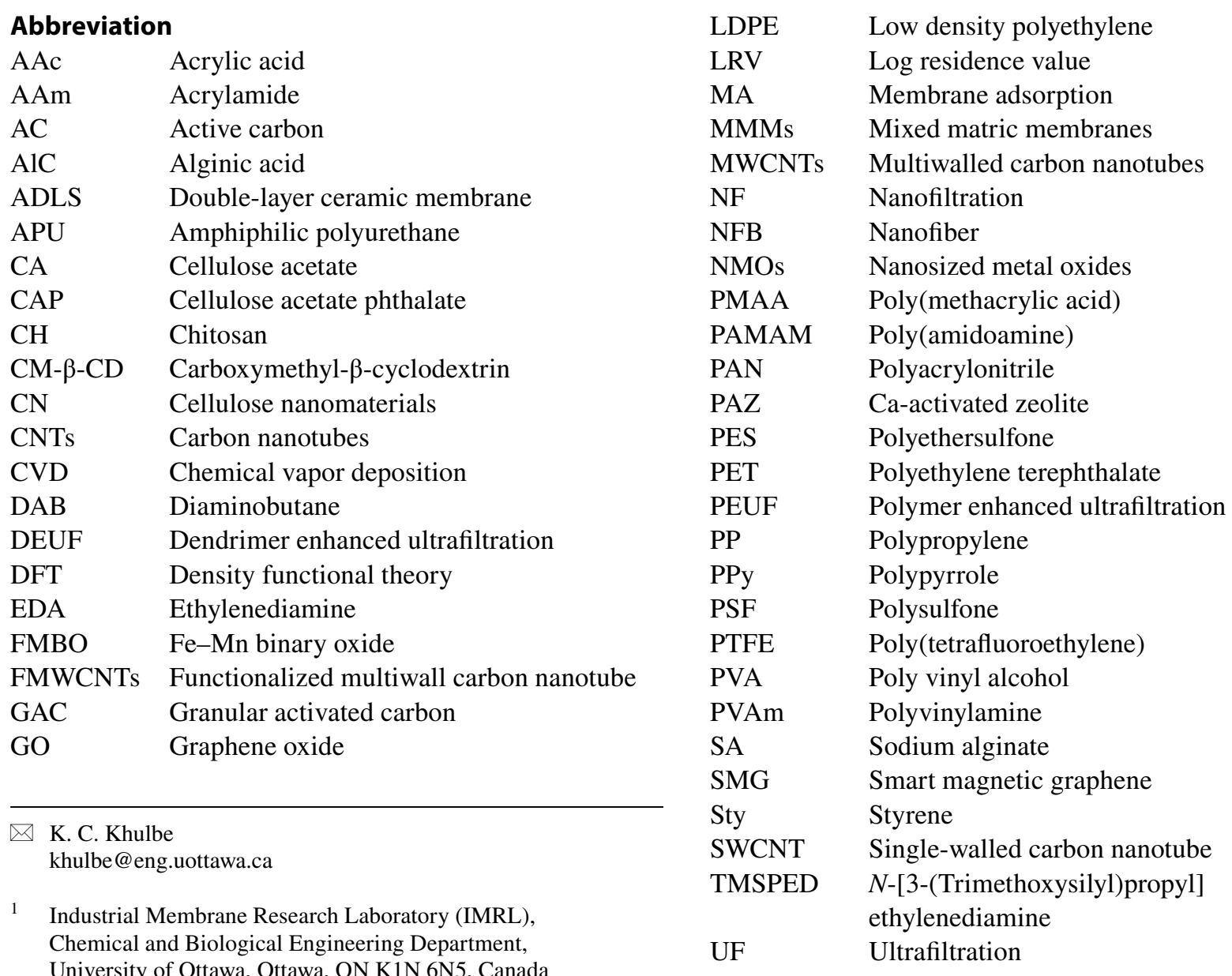

University of Ottawa, Ottawa, ON K1N 6N5, Canada 
ZNM Zein nanofibrous membrane

ZVI

Zero valent iron

\section{Introduction}

"When the Well's dry, we know the worth of water", Franklin (1746) quoted those prophetic words nearly two and a half centuries ago. Now, those wells are in danger of running dry, and we are facing a critical shortage of clean and fresh water. The problem is not the supply of water. Earth has virtually the same amount today as it had at Dinosaur's period. We are the cause for acute shortage of fresh water (drinking) due to our flagrant abuse of one of our precious and limited resources. Water pollution due to organic contaminants is a serious issue because of acute toxicities and carcinogenic nature of the pollutants.

The maximum contaminant level (MCL) standards, for those heavy metals, established by United States Environmental Protection Agency (USEPA) (Babel and Kurniawa 2003) are summarized in Table 1.

So far, a number of efficient methods have been reviewed for the removal of heavy metals such as chemical precipitation, ion exchange, reverse osmosis, electrodialysis, ultrafiltration, nanofiltration, coagulation, flocculation, floatation, etc. However, these methods have several disadvantages such as high reagent requirement, unpredictable metal ion removal, generation of toxic sludge, etc. Adsorption process being very simple, economical, effective and versatile has become the most preferred methods for removal of toxic contaminants from wastewater (Lakherwa 2014). Comparatively, the adsorption process seems to be a significant technique due to its wide applications, such as ease of operation, economic feasibility, wide availability and simplicity of design (Malik et al. 2016). Among the aforementioned methods, adsorption is considered to be one of the most appropriate techniques, but there are disadvantages to this method, including small capacity, high cost, difficulty for large-scale application, etc. The adsorbents may be of mineral, organic or biological origin: activated carbons, zeolites, clay, silica beads, low-cost adsorbents (industrial by-products, agricultural wastes, biomass) and polymeric materials (organic polymeric resins, macroporous hyper crosslinked polymers) are significant examples (Crini 2005; Bobade and Eshtiag 2015). Huang et al. (1985) evaluated the activated carbon adsorption process for the removal of $\mathrm{Co}$ (II) from solution with special emphasis placed on the effect of various organic substances on Co(II) removal. Their results showed Co(II) was removed by adsorption rather than be precipitation alone. Fourteen types of activated carbons were evaluated for their $\mathrm{Co}$ (II) removal capabilities. Two activated carbons, Nuchar SA and Nuchar SN, gave similar high metal removal capacities (removals approached $100 \%$, depending on the solution $\mathrm{pH}$ ). The $\mathrm{Co}$ (II) removal percentage decreased with increasing surface loadings.

Al-Rashdi et al. (2011) reported the removal of some heavy metals [Cu(II), $\mathrm{Cd}(\mathrm{II}), \mathrm{Mn}(\mathrm{II}), \mathrm{Pb}(\mathrm{II}) \mathrm{As}(\mathrm{III})$, and $\mathrm{As}(\mathrm{V})]$ from aqueous solution using adsorption and nanofiltration membrane techniques. Table 2 shows the results (removal of heavy metals) obtained by nanofiltration (NF) and by adsorption on different materials.

\section{Membrane adsorption process}

\section{General theory of metals adsorption on membrane surface}

Membrane separation has been increasingly used recently for the treatment of inorganic effluent due to its convenient operation. Membrane adsorbent technology is a membrane integration technology that was developed in the mid-1980s (Avramescu et al. 2003, 2008). Adsorption is a mass transfer process by which a substance is transferred from the liquid phase to the surface of a solid, and becomes bound by physical and/or chemical interactions. The heavy metal ions in the aqueous solution can be captured by the adsorbent though the physical or chemical adsorption. Generally, chemical adsorption is more popular for heavy metal removal because it has stronger interactions and higher adsorption capacity

Table 1 The MCL standards for the most hazardous heavy metals (Babel and Kurniawa 2003)

\begin{tabular}{lll}
\hline Heavy metal & Toxicities & MCL (mg/L) \\
\hline Arsenic & Skin manifestations, visceral cancers, vascular disease & 0.050 \\
Cadmium & Kidney damage, renal disorder, human carcinogen & 0.01 \\
Chromium & Headache, diarrhea, nausea, vomiting, carcinogenic & 0.05 \\
Copper & Liver damage, Wilson disease, insomnia & 0.25 \\
Nickel & Dermatitis, nausea, chronic asthma, coughing, human carcinogen & 0.20 \\
Zinc & Depression, lethargy, neurological signs and increased thirst & 0.80 \\
Lead & Damage the fetal brain, diseases of the kidneys, circulatory system, and nervous system & 0.006 \\
Mercury & Rheumatoid arthritis, and diseases of the kidneys, circulatory system, and nervous system & 0.00003 \\
\hline
\end{tabular}


Table 2 Results (removal of heavy metals) obtained by NF (nanofiltration) and by adsorption

\begin{tabular}{llll}
\hline Material/membrane & Heavy metals & Removed by NF membrane $(\%)$ & Removed by adsorbent \\
\hline $\begin{array}{l}\text { Montmorillonite, kaolin, tobermorite, magnet- } \\
\text { ite, silica gel and alumina }\end{array}$ & $\mathrm{Cd}(\mathrm{II})$ & $97 \%\left(\mathrm{C}_{0}=500 \mathrm{ppm}\right)$ & $\begin{array}{c}80 \% \text { from a solution of initial concentration } \\
\text { range } 1-100 \mathrm{ppm}\end{array}$ \\
$\begin{array}{l}\text { Chitosan coated magnetic nanoparticles modi- } \\
\text { fied with } \alpha \text {-ketoglutaric acid }\end{array}$ & $\mathrm{Cu}(\mathrm{II})$ & $99.9 \%\left(\mathrm{C}_{0}=12,000 \mathrm{ppm}\right)$ & $\begin{array}{c}>95 \% \text { from a solution of initial concentration } \\
200 \mathrm{ppm}\end{array}$ \\
$\begin{array}{l}\text { Polymeric cation exchanger containing nano- } \\
\mathrm{Zr}\left(\mathrm{HPO}_{3}-\mathrm{S}\right)_{2}\end{array}$ & $\mathrm{~Pb}(\mathrm{II})$ & $84 \%\left(\mathrm{C}_{0}=0.64 \mathrm{ppm}\right)$ & $98 \%$ with initial concentration $80 \mathrm{ppm}$ \\
Acid modified carbon & $\mathrm{As}(\mathrm{V})$ & $93 \% \mathrm{As}(\mathrm{V})$ and $89 \% \mathrm{As}(\mathrm{III})$ & $\sim 80 \%$ with initial concentration $200 \mathrm{ppm}$ \\
& & $\left(\mathrm{C}_{0}=600 \mathrm{ppm}\right)$ & $98.7 \%$ with initial concentration \\
Polonite & $\mathrm{Mn}(\mathrm{II})$ & $98 \%\left(\mathrm{C}_{0}=310 \mathrm{ppm}\right)$ & $0.01 \pm 0.031 \mathrm{ppm}$ \\
\hline
\end{tabular}

$C_{0}$ initial concentration

towards heavy metals. The special functional groups on the surface of the adsorbents provide significant interactions with heavy metals, resulting in the adsorptive separation of heavy metals from water.

Adsorption is a very significantly economic, convenient and easy operation technique. It shows high metal removal efficiency and is applied as a quick method for all types of wastewater treatments. It is becoming a popular technique, because in this process the adsorbent can be reused and metal recovery is possible. Thus, there are two types of adsorption:

1. Chemical adsorption is also referred to as activated adsorption: the adsorbate can form a monolayer. It is also utilized in catalytic operations. In general, the main steps involved in adsorption of pollutants on solid adsorbent are:

(a) Transport of the pollutant from bulk solution to external surface of the adsorbent. Internal mass transfer is carried by pore diffusion from outer surface of adsorbent to the inner surface of porous structure.

(b) Adsorption of adsorbate on the active sites of the pores of adsorbent. The overall rate of adsorption is decided by either film formation or intra-particle diffusion or both as the last step of adsorption are rapid as compared to the remaining two steps.

2. Physical adsorption: it is a general incident and occurs in any solid/liquid or solid/gas system. Physical adsorption is a process in which binding of adsorbate on the adsorbent surface is caused by van der Waals forces of attraction.

It is well known that $\mathrm{pH}$ is an important parameter for adsorption of metal ions from aqueous solution because it affects the solubility of the metal ions in water, concentration of the counter ions on the functional groups of the adsorbent and the degree of ionization of the of the adsorbate during reaction.

A membrane adsorbent is made by connecting functional groups to the surface and pore wall of polymer membranes; the target pollutants are selectively adsorbed to the functional group. The membrane adsorbent effectively combines the filtration performance of the membrane. When the contaminated water flows through the membrane, the functional active binding sites will combine with the target pollutants to remove contaminants from drinking water with a high adsorption rate and capacity because of the very short contact distance at a submicron-scale level between the target pollutants to the adsorbed active binding site of the membrane adsorbents (Fig. 1) (Zheng et al. 2014).

Currently, adsorption is regarded as the most favorable method for water cleansing, but common adsorbents, including activated carbon, zeolites and natural fibers, suffer from low adsorption capacities, poor selective sorption and unsatisfactory regeneration ability. A number of advanced adsorbents, including nanostructured metal oxides, carbon

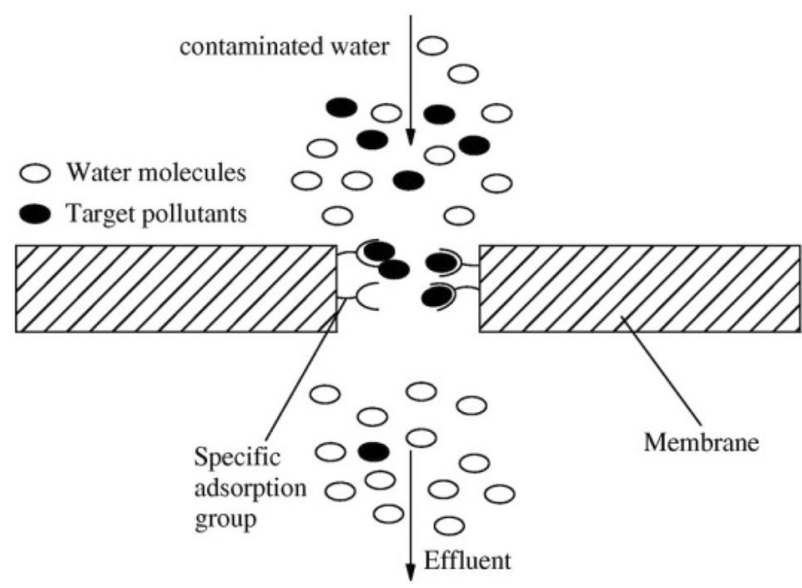

Fig. 1 The principle of membrane adsorbent 
nanotubes, porous boron nitride nanosheets and porous graphene, among others, have been developed to overcome these shortcomings (Yang et al. 2015b). It is well known that activated carbons possess a large surface area with different surface functional groups, including carboxyl, carbonyl, phenol, quinone, lactone and other groups bound to the edges of the graphite-like layers. They are therefore regarded as good adsorbents for the removal of heavy metal ions and other inorganic substances. Bobade and Eshtiag (2015) wrote a review entitled 'Heavy metals removal from wastewater by adsorption process' which was focused on the heavy metals removal based on the performance of various adsorbents such as natural materials, industrial byproduct, agricultural and biological waste, biopolymers and hydrogels.

\section{Polymeric membranes for membrane adsorption}

Traditional polymeric adsorbents were first developed in the 1960s (Kunin 1976). In membrane adsorption, contaminants are adsorbed to the functional groups of the membrane or to the sorbent incorporated in the support membrane while the waste water permeates through the membrane. Many synthesized polymers or biopolymers with special functional groups (e.g., amine, carboxyl, and sulfonic acid) also show efficient adsorption capacity for heavy metal ions (Vieira and Beppu 2005; Saber-Samandari and Gazi 2013). Those functional groups play a dominant role in the adsorptive removal of heavy metals, regenerated after the adsorbents are saturated by removing the adsorbed contaminants.

Different heavy metal ions especially $\mathrm{Cr}(\mathrm{VI}), \mathrm{Zn}(\mathrm{II})$, and $\mathrm{Pb}$ (II) can be removed from wastewater by conducting polymer-based adsorbents. Polypyrrole (PPy) based adsorbents play a major role for the removal of various heavy metal ions due to their ease of synthesis, biocompatibility and redox properties. The most common polypyrrole-based adsorbents towards the removal of heavy metal ions are PPy/ biosorbents, $\mathrm{PPy} / \mathrm{Fe}_{3} \mathrm{O}_{4}$ nanocomposites, $\mathrm{PPy}$-polyaniline nanofibers, PPy-graphene nanocomposites, exfoliated PPyorganically modified clay nanocomposites, and hierarchical porous PPy-nanoclusters (Mahmud et al. 2016).

Padmavathi et al. (2014) from the four different waste water industries such as:

\section{Fertilizer,}

2. Sewage,

3. Tannery,

4. Dye industry.

Two different anion exchange polymers, i.e. quaternized polysulfone (QPSF) and poly styrene ethylene butylene poly styrene (QPSEBS) membranes were used as adsorbents and the adsorption study was done by batch adsorption process. Influence of contact time on adsorption process was evaluated. Before and after the adsorption process, the membranes were characterized using scanning electron microscopy (SEM). The concentration of the metal ions after adsorption process was determined by inductively coupled plasma optical emission spectroscopy (ICP-OES). The tannery water showed more $\mathrm{Cr}^{6+}$ content and was removed by the adsorbents efficiently up to $30 \%$ using QPSF membranes.

Low-density polyethylene (LDPE) films were grafted by styrene/acrylic acid and by styrene/acrylamide using gamma-radiation to obtain membranes were used in the removal of the different heavy metals pollutants: such as (U, Zr, V and Mo) from wastewater (Dessouki et al. 2000).

1. Low-density polyethylene-styrene/acrylic acid copolymer (LDPE-g-Sty/AAc).

2. Low-density polyethylene-styrene/acrylamide copolymer (LDPE-g-Sty/AAm).

3. Polypropylene-styrene/acrylic acid copolymer (PP-gSty/AAc).

4. Polypropylene-styrene/acrylamide copolymer (PP-g-Sty/ AAm) PP.

It was reported that LDPE-gSty/AAc showed less adsorption capacity than the LDPE-g-Sty/AAm membranes, for all heavy metal pollutants, which could be possible by the functional groups grafted on the trunk polymer. Uranium and zirconium showed higher affinity towards the membrane compared with vanadium and molybdenum which could be expected from the following reasons:

1. Difference in molecular weight,

2. Molecular size,

3. Valance (generally the different physico-chemical characteristics).

It was also reported that the grafted polypropylene membranes showed higher adsorption capacity than the grafted polyethylene membranes for all pollutants at various $\mathrm{pH}$ values.

Senna et al. (2013) prepared membranes from a graftcopolymer, polyethylene (HDPE) substrate grafted by acrylamide using radiation, with functional groups for the removal of metals and phosphate anions. For the removal of phosphate ions from aqueous solutions, a chemically modified membrane loaded with $\mathrm{Cu}^{2+}$ was used. Figure 2 shows the effect of the initial phosphate concentration on the uptake behavior of HDPE-g-PAAm treated with ethylenediamine/phthalic unhydride and loaded with $\mathrm{Cu}(\mathrm{II})$. From Fig. 2, it seems that the adsorption capacity for phosphate ions increased almost linearly with increasing feed concentration. The concentration of phosphate ions adsorbed was $100 \mathrm{mg} / \mathrm{g}$ polymer. The absorbent was regenerated by 


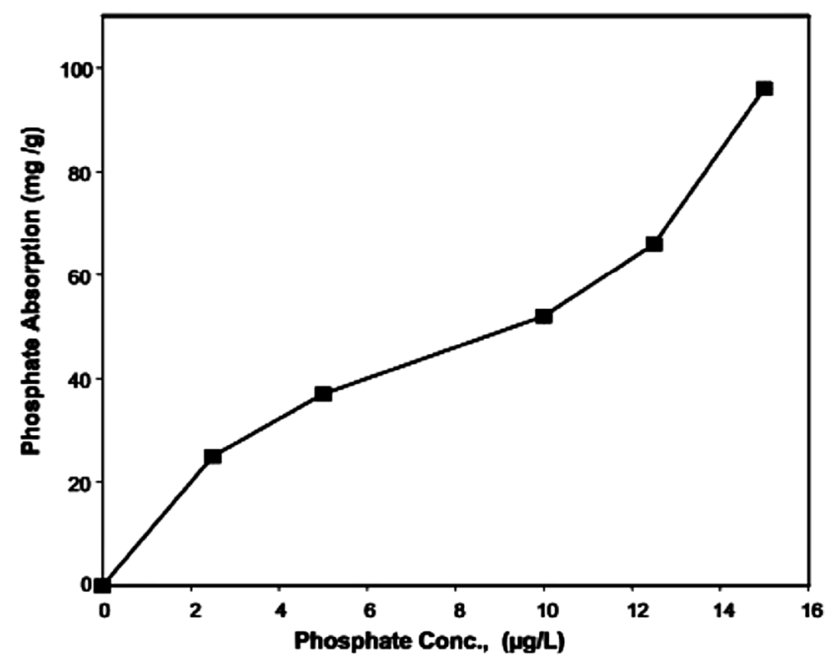

Fig. 2 Effect of the initial phosphate concentration on the uptake behavior of HDPE-g-PAAm treated with ethylenediamine/phthalic unhydride and loaded with $\mathrm{Cu}$ (II) (Senna et al. 2013)

washing with $6 \% \mathrm{NaCl}$, which resulted in the recovery of approximately $98.8 \%$ of its original performance.

Ritchie et al. (1999) prepared cellulosic membrane-based sorbents, functionalized with polyamino acids and observed high-capacity (3-14 mmol metal/g of sorbent) metal $\left(\mathrm{Pb}^{2+}\right.$, $\mathrm{Cu}^{2+}$, and $\mathrm{Cd}^{2+}$ ) sorption. It was revealed that silica-based membrane sorbents possess metal sorption capacities nearly to those of cellulosic-based membranes. Beside this, silicabased membranes had excellent acid and solvent resistance. Metal sorption capacities of silica-based membrane sorbents with various polyamino acids ranged from 0.6 to $1.4 \mathrm{mmol}$ metal/g of sorbent. Wang et al. (2013) developed a microfiltration membrane, based on a two-layered nanoscale polyacrylonitrile (PAN)/microscale polyethylene terephthalate (PET) fibrous scaffold containing infused ultra-fine functional cellulose nanofibers (diameter about $5 \mathrm{~nm}$ ). It was demonstrated by Wang et al. that these membranes can simultaneously remove bacteria, viruses and/or toxic heavy metal ions. These membranes were capable of completely removing Escherichia coli (by size extrusion), reaching a log residence value (LRV) of 4 for MS2 virus removal and having the adsorption capability of $100 \mathrm{mg} \mathrm{Cr}^{6+}$ or $260 \mathrm{mg} \mathrm{\textrm {Pb } ^ { 2 + }}$ per gram of cellulose nanofiber, while maintaining a high permeation rate $\left(1300 \mathrm{~L} / \mathrm{m}^{2} \mathrm{~h} / \mathrm{psi}\right)$. The development of these membranes was based on the creation of a web-like structure with very high charge density and large surface area per unit volume for adsorption of contaminant molecules.

Yoo and Kwak (2013) fabricated a functionalized membrane by surface amination of PTFE [poly(tetrafluoroethylene)] membrane with hydrazine, followed by chemical coupling with the hydrophilic chelating agent hyperbranched poly(amidoamine) (HPAMAM).
Coupling of HPAMAM to PTFE membranes greatly enhanced water flux including the removal of $\mathrm{Cu}^{2+}$ ions from aqueous solution, with an adsorption capacity of $1.42 \mathrm{~g} / \mathrm{m}^{2}$, with about $90 \%$ desorption under acidic condition. The adsorption capacity for $\mathrm{Cu}^{2+}$ ions was favorably preserved with reusing cycles. Overall, these results indicate the potential applicability of HPAMAM-grafted PTFE microfiltration membranes as highly efficient and reusable materials for the removal of heavy metal ions.

Wang et al. (2016) investigated the phosphate adsorption by a polyethersulfone-type affinity membrane using experimental and DFT (density functional theory) methods. The polyethersulfone (PES)-type affinity membrane was prepared via the chloroacetylation and amination processes. Influences of $\mathrm{Cl}^{-}, \mathrm{Ca}^{2+}$, and $\mathrm{Mg}^{2+}$ on the phosphate uptake were also studied. Figure 3 shows the effects of $\mathrm{pH}$, temperature, contact time, and initial phosphate concentration on phosphate adsorption by the DETA-PES affinity membrane. The phosphate uptake of the DETA-PES affinity membrane was strongly dependent on the value of $\mathrm{pH}$. The phosphate uptake of the DETA-PES membrane increases when $\mathrm{pH}$ rises from 2.0 to 4.0. The optimal $\mathrm{pH}$ for the phosphate adsorption is 4.0. It was suggested that phosphate was removed by the membrane in the form of $\mathrm{H}_{2} \mathrm{PO}^{4-}$.

The phosphate uptake of DETA-PES affinity membrane as a function of time at different temperatures is shown in Fig. 3b. The phosphate uptake of DETA-PES membrane increases significantly with increasing concentration of the initial phosphate (Fig. 3c). The phosphate uptake of the membrane at $298 \mathrm{~K}$ rises from 15.1 to $52.2 \mathrm{mg} \mathrm{P} / \mathrm{g}$, when the initial phosphate concentration increases from 20 to $120 \mathrm{mg}$ $\mathrm{P} / \mathrm{L}$. It was also reported that the affinity of the protonated DETA-PES membrane to phosphate was stronger than that to $\mathrm{Cl}^{-}$and, due to the maximum charge transfer between phosphate and the (DETA-PES- $\left.\mathrm{H}_{n}\right)^{+}$chain, and the more negative adsorption energy and Gibbs free energy of adsorption for the formed (DETA-PES- $\left.\mathrm{H}_{n}\right)^{+}-\mathrm{H}_{2} \mathrm{PO}_{4}$ complex.

Vieira and Beppu (2006) synthesized glutaraldehydecrosslinked chitosan membrane by the static method. Chitosan can be molded in several shapes, such as membranes, microspheres, gel beads and films, and is able to provide a surface-area-to-mass ratio that maximizes the adsorption capacity and minimizing hydrodynamic limitations effects. Vieira and Beppu (2006), using natural and crosslinked chitosan, confirmed the removal of $\mathrm{Hg}^{2+}$ ions from aqueous solutions. Figure 4 shows the possible structure formed from crosslinking by glutaraldehyde.

It was revealed that the amounts of $\mathrm{Hg}^{2+}$ ions adsorbed and desorbed were influenced by parameters such as the initial $\mathrm{Hg}^{2+}$ concentration, crosslinking with glutaraldehyde and the adsorbent shape. The adsorption capacity determined by the dynamic method was 65 and $77 \%$ for

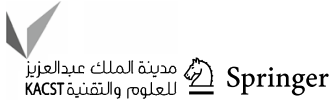



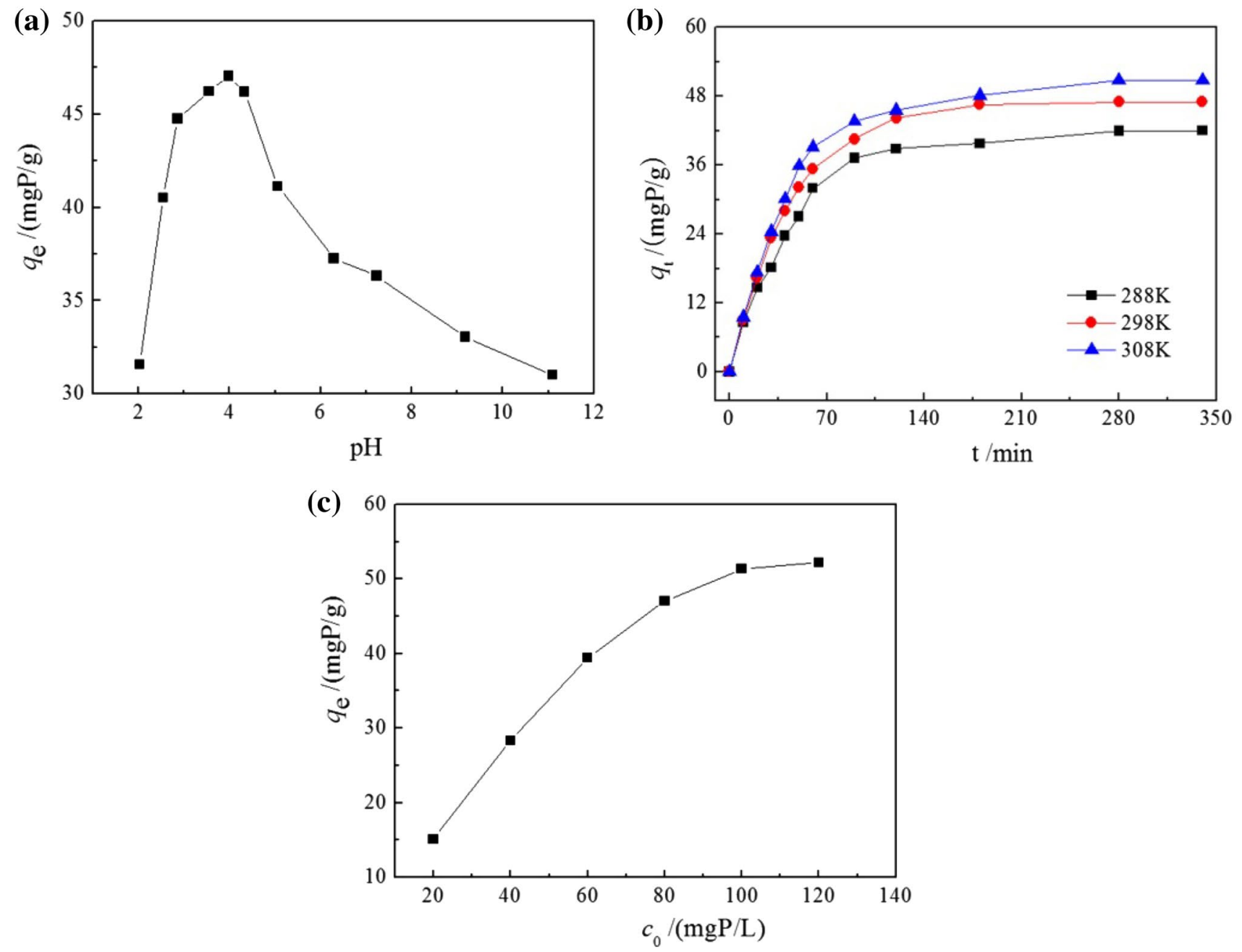

Fig. 3 Effects of $\mathrm{pH}$, temperature, contact time, and initial phosphate concentration on phosphate adsorption by the DETA-PES affinity membrane: a $\mathrm{pH}\left[\mathrm{c}_{0}\right.$ (phosphate $)=80 \mathrm{mg} \mathrm{P} / \mathrm{L} ; t: 360 \mathrm{~min}$; membrane dry weight: $0.1 \mathrm{~g} ; T: 298 \mathrm{~K}$; b temperature and contact time

membranes and spheres, respectively, of the value obtained static method results.

Nafion 117 membrane was investigated by Nasef and Yahaya (2009) for the removal of $\mathrm{Ni}(\mathrm{II}), \mathrm{Co}(\mathrm{II}), \mathrm{Pb}(\mathrm{II})$, $\mathrm{Cu}(\mathrm{II})$ and $\mathrm{Ag}(\mathrm{I})$ metal ions via adsorption from their synthesized aqueous solutions. The affinity of Nafion 117 membrane towards heavy metal ions was found to be in the sequence:

$\mathrm{Cu}($ II) $>\mathrm{Ni}$ (II) $>\mathrm{Co}(\mathrm{II})>\mathrm{Pb}$ (II) $>\operatorname{Ag}(\mathrm{I})$,

The desorbed Nafion 117 membranes were found to be able to adsorb of all metal ions even after five cycles conducted.

Muthulakshmi and Anuradha (2015) surveyed on the adsorption capacity of chitosan derivatives prepared by five different methods (thiocarbonyl, PVA blend, xanthate, Nano based and grafting) and concluded that chitosan $\left[\mathrm{c}_{0}\right.$ (phosphate $)=80 \mathrm{mg} \mathrm{P} / \mathrm{L}$; membrane dry weight: $0.1 \mathrm{~g} ; \mathrm{pH} 4.0$ ]; $\mathbf{c}$ initial phosphate concentration (membrane dry weight: $0.1 \mathrm{~g}$; $\mathrm{pH} 4.0$; $t: 360 \mathrm{~min} ;$ T: $298 \mathrm{~K}$ ) (Wang et al. 2016)

grafted with $\gamma$-cyclodextrin possesses better chelating ability in isolating $\mathrm{Cd}^{2+}$ ions from waste water.

The binding properties of alginate with divalent cations have been studied by Fatin-Rouge et al. (2006) showing an increasing affinity for $\mathrm{Ca}^{2+}$ over $\mathrm{Mg}^{2+}$ as polymer concentration increases, and the relative affinity $\mathrm{Pb}^{2+}>$ or $=\mathrm{Cu}^{2+}>\mathrm{Zn}^{2+}>\mathrm{Ni}^{2+}$. It was reported that alginate can be used for the softening of hard water.

Li et al. (2016a, b) used polyethylenimine-grafted gelatin sponge for the removal of $\mathrm{Pb}$ and $\mathrm{Cd}$ ions from waste water irrigation. The removal efficiencies for lead ions and cadmium ions were 89.9 and $79.7 \%$, respectively. He et al. (2008) prepared an activated nylon-based membrane modified by chitosan and examined its adsorption behavior for $\mathrm{Cu}^{2+}$ ions, the result revealed that its adsorption capacity 


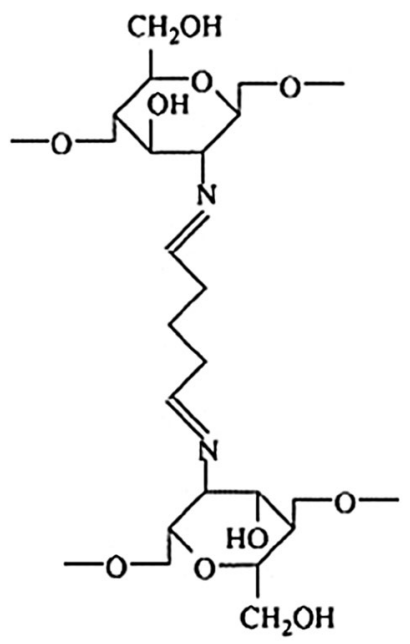

Fig. 4 Possible structure formed from crosslinking, using glutaraldehyde

for $\mathrm{Cu}^{2+}$ ions could arrive at $10.794 \mathrm{mg} / \mathrm{g}$; demonstrating a large affinity for metal $\mathrm{Cu}^{2+}$ ions.

Gohari et al. (2013) synthesized PES/FMBO (Fe-Mn binary oxide) MMMs via phase inversion for the adsorptive removal of As(III) from aqueous solution. It was reported that PES/FMBO mixed matrix membranes could be utilized for effective removal of $\mathrm{As}$ (III) in a broad $\mathrm{pH}$ range (2-8). The continuous UF experiment showed that the PES/FMBO mixed matrix membrane could be potentially utilized for effective removal of As(III) from contaminated solution by maintaining the As(III) concentration of permeate solution below the MCL of 10 ppb. He et al. (2014) designed a $\mathrm{Zr}$ based nanoparticle embedded PSF hollow fiber membrane for removal of arsenate ion $\left(\mathrm{AsO}_{4}{ }^{3-}\right)$ from water. It was observed that the maximum adsorption capacity of arsenate on the membrane was as high as $131.78 \mathrm{mg} / \mathrm{g}$ under experimental conditions. Chatterjee and De (2014) prepared MMMs from cellulose acetate phthalate (CAP) and activated granular alumina using phase inversion technique and used them for the separation of fluoride ion from water. It was observed that the permeability of the membrane was reduced from $3.0 \times 10^{-11}$ to $1.4 \times 10^{-11} \mathrm{~m} / \mathrm{Pa} \mathrm{s}$ as alumina concentration increased from 0 to $35 \mathrm{wt} \%$ for constant CAP concentration at $20 \mathrm{wt} \%$. Fluoride rejection from contaminated water increased to $91 \%$ using $35 \mathrm{wt} \%$ of alumina. Maximum adsorption capacity for fluoride was $2.3 \mathrm{mg} / \mathrm{g}$ for the mixed matrix membrane at room temperature. Zhang et al. (1999) satisfactorily removed $\mathrm{Cd}^{2+}$ and $\mathrm{Sr}^{2+}$ ions via adsorption on cellulose/alginic acid ( $\mathrm{RC}-\mathrm{AlC}$ ) ion-exchange membrane. Vinodhini and Sudha (2016) fabricated a novel ultrafiltration membrane prepared by phase inversion method using cellulose acetate, nano chitosan, and polyethylene glycol. The membrane was used for toxic hexavalent chromium removal from tannery effluent.
Much effort was made to fabricate new hybrid membranes as adsorbents to remove metals from water (Liu and Wang 2013; Liu et al. 2011; Dong et al. 2011; Zhang et al. 2013). These hybrid membranes exhibited excellent adsorption properties for heavy-metal ions in aqueous solution. Zhu et al. (2014a, b) fabricated a series of zwitterionic hybrid membrane via the ring opening of 1,3-propanesultone with the amine groups in the chains of $\mathrm{N}$-[3(trimethoxysilyl)propyl] ethylenediamine (TMSPED) and a subsequent sol-gel process. These hybrid membranes were used as adsorbents to remove single strontium ions from the stimulated radioactive wastewater. The experimental data were analyzed using various typical models and the following results were achieved from hybrid membranes;

1. Lagergren pseudo-second-order model was the best for the adsorption of strontium ions on the zwitterionic hybrid membranes.

2. Chemisorption cannot be used to describe the adsorption behaviors of strontium ions on these zwitterionic hybrid membranes as resulted using Elovich model.

3. Mechanism studies demonstrated that intraparticle diffusion was not the solely controllable process, and diffusion-chemisorption might be more rational to explain the adsorption of strontium ions on these zwitterionic hybrid membranes. Meanwhile, Boyd equation showed that the adsorption was film-diffusion mechanism.

However, more research is needed for the application of zwitterionic hybrid membranes as adsorbents including improvement of selectivity in practical use.

Zheng et al. (2014) demonstrated the removal of heavy metal in drinking water using a new type of cation-exchange resin mixed polyethersulfone (PES) membrane adsorbent. Cation-exchange resins (Type 110-H) were incorporated into the PES porous matrix synthesized by the immersion phase separation method. High values of heavy metal ion adsorption capacities of $361.79 \mathrm{mg} \mathrm{Hg}^{2+} / \mathrm{g}, 264.33 \mathrm{mg} \mathrm{Pb}^{2+} / \mathrm{g}$, and $94.75 \mathrm{mg} \mathrm{Cu}^{2+} / \mathrm{g}$ for resin Type $110-\mathrm{H}$ mixed PES membrane adsorbent with $65 \%$ resin loading were obtained by the static adsorption test. The adsorption capacity of the membrane adsorbents was affected by the amount of resin loading and adsorbing time. In comparison with resin Type 110-H, the membrane adsorbents have a higher adsorption capacity with heavy metal ions. The dynamic capacity experiment was performed by passing the $\mathrm{Cu}^{2+}$ solution through a stack of three pieces of flat-sheet membranes. The $\mathrm{Cu}^{2+}$ mass adsorbed per unit mass of membrane was calculated at a breakthrough concentration (20\% of the feed concentration). The dynamic $\mathrm{Cu}^{2+}$ binding capacity was $6.25 \mathrm{mg} / \mathrm{g}$ membrane, and the desorption rate of the membrane adsorbent was up to $97.6 \%$. The adsorption isotherm was fitted with

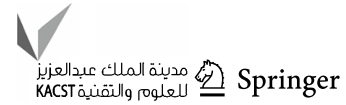


the Langmuir model with a maximum adsorption capacity of $161.29 \mathrm{mg} \mathrm{Cu}^{2+} / \mathrm{g}$ of the membrane.

Said et al. (2015) fabricated active carbon (AC) membrane supported on polysulfone (PSF) composite membrane that consisted of polyethyleneimine and silver nitrate via phase inversion. The activated carbon (AC) acted as adsorbent to adsorb heavy metal present in synthetic waste water. The composite membrane with $0.9 \mathrm{wt} \% \mathrm{AC}$ has the higher water flux as well as removal of heavy metal (chromium, lead, silver and cadmium) compared to the composite membrane with $0.3 \mathrm{wt} \% \mathrm{AC}$ and $0.5 \mathrm{wt} \% \mathrm{AC}$. The percentage of heavy metal reduction by composite membrane with 0.9 wt $\%$ AC was $35 \%$ cadmium, $19 \%$ chromium, $16 \%$ silver and $2 \%$ lead. The concentration of AC plays an important role towards enhancing the adsorption of heavy metal in water.

Algarra et al. (2014) developed diaminobutane based poly(propyleneimine) dendrimer functionalized with 16 thiol groups, DAB-3-(SH)16, embedded in a swollen cellulosic support to achieve an easily handle engineered membrane. The membrane was characterized by physicochemical, electrical and transport measurements, and the effect of the dendrimer was established by comparing these results with those obtained for the original cellulosic support. The results show that dendrimer inclusion improves the membrane elastic behavior (Young modulus increase around 20\%) including a significant reduction in the permeation of toxics heavy metals $\left(\mathrm{Cd}^{2+}, \mathrm{Hg}^{2+}\right.$ and $\left.\mathrm{Pb}^{2+}\right)$. Thus, these membranes can be utilized for water remediation without negatively affecting their rejection property as well as increasing its ability to remove $\mathrm{Cu}^{2+}$ ions in aqueous solution. Katsoyiannis and Zouboulis (2002) removed the arsenic via adsorptive filtration using modified polymeric materials (polystyrene and polyHIPE) by coating their surface with appropriate adsorbing agents (i.e. iron hydroxides). It was reported that modified membranes were capable of removing arsenic from the aqueous stream, leading to residual concentration of this toxic metalloid element below $10 \mu \mathrm{g} / \mathrm{L}$.

Bessbousse et al. (2008) synthesized a novel composite membrane composed of adsorbents and polymer matrices. The membrane consists of a semi-interpenetrating polymer network of crosslinked poly(vinyl alcohol) as the matrix and poly(ethyleneimine) as the complexing polymer and was used for the removal of heavy metal ions such as $\mathrm{Pb}^{2+}$, $\mathrm{Cd}^{2+}$ and $\mathrm{Cu}^{2+}$ from aqueous solutions. The affinity order of the membrane was $\mathrm{Pb}>\mathrm{Cu}>\mathrm{Cd}$, with the uptake of the ions per gram of membrane: $0.59,0.47$ and $0.33 \mathrm{~m} \mathrm{~mol} / \mathrm{g}$, respectively. On the other hand, the uptake order is different on a mass basis: 123,30 and $37 \mathrm{mg} / \mathrm{g}$, respectively.

Hermassi et al. (2016) studied the feasibility of continuous phosphate recovery, by adsorption on powdered $\mathrm{Ca}$ activated zeolite (PAZ), via in a hybrid sorption-membrane ultrafiltration (UF) system, and also evaluated the hydrodynamic parameters of the UF operation as function of PAZ. It was reported that the $\mathrm{P}(\mathrm{V})$ recovery profiles as a function of the initial $\mathrm{P}(\mathrm{V})$ concentrations was, at $\mathrm{pH} 8$ and $2.5 \mathrm{gPAZ} / \mathrm{L}$. It indicated that the sorbent was not saturated, and recoveries reported were $1.8 \pm 0.2,5.7 \pm 0.3$, and $47.2 \pm 2 \mathrm{mg} \mathrm{P}(\mathrm{V}) /$ gPAZ for $10 \pm 1,25 \pm 2$, and $100 \pm 6 \mathrm{mg} \mathrm{P}(\mathrm{V}) / \mathrm{L}$, respectively. The increase of the $\mathrm{pH}$ of the feed solution from 8 to 9 increased the $\mathrm{P}(\mathrm{V})$ recovery up to $70 \pm 4 \%$. A P $(\mathrm{V})$ fractionation protocol of the loaded samples confirmed that the phosphate-sorption process involves the formation of calcium phosphate mineral forms.

Saffaj et al. (2004) used low-cost $\mathrm{ZnA1}_{2} \mathrm{O}_{4}-\mathrm{TiO}_{2}$ ultrafiltration membranes for removing $\mathrm{Cd}$ (II) and $\mathrm{Cr}(\mathrm{III})$ ions from water. The membrane presents interesting retention properties with regard to the heavy metal ions and dyes. Their retention depends strongly on the concentration and on the $\mathrm{pH}$ of the filtered solution. It was noticed that $93 \% \mathrm{Cd}^{2+}$ rejection and $86 \% \mathrm{Cr}^{3+}$ rejection were achieved. Depending on the membrane characteristics, UF can achieve more than $90 \%$ of removal efficiency with a metal concentration ranging from 10 to $112 \mathrm{mg} / \mathrm{L}$ at $\mathrm{pH}$ ranging from 5 to 9.5 and at 2-5 bar of pressure. Dorraji et al. (2014) prepared $\mathrm{Fe}$ (III)-loaded chitosan (CH) hollow fibers [CH-Fe(III) HF] via dry-wet spinning technique. Removal of pentavalent arsenic was studied through biosorption on CS-Fe(III) HF adsorptive membranes.

Krason and Pietrzak (2016) studied the removal of $\mathrm{Fe}^{3+}$ and $\mathrm{Cu}^{2+}$ ions from liquid phase using cellulose acetate membrane containing polyvinylpyrrolidone (PVP) as a cross-linker agent. It was revealed that the surface had oxygen-containing groups of acidic character and depends on the PVP content and have role in ion removal.

Chen et al. (2010) fabricated $\mathrm{Cr}$ (III) ionic imprinted membrane adsorbents [Cr(III)-PVA/SA] by blending sodium alginate (SA) with polyvinyl alcohol (PVA). Cr(III)-PVA/ SA exhibited the maximum $\mathrm{Cr}$ (III) ions uptake capacity of $59.9 \mathrm{mg} / \mathrm{g}$ under some conditions. Consecutive adsorption-desorption for five experiments showed that the $\mathrm{Cr}$ (III)PVA/SA has high adsorption and desorption efficiencies.

Polymer enhanced ultrafiltration (PEUF) process opens a new process for purifying the contaminated water by recovering metal ions. In this process, a water-soluble polymer with strong binding affinity for the target metal ions is added to contaminated water. The metal ion bound to the polymer is then removed by UF membrane having pore sizes smaller than those of the metal ion-polymer complexes.

Diallo et al. (2004) made detailed investigations on the uptake of $\mathrm{Cu}$ (II) by poly(amidoamine) (PAMAM) dendrimers with an ethylenediamine (EDA) core in aqueous solutions by the UF membrane. In another article, Diallo et al. (2005) discussed the feasibility of using dendrimer enhanced ultrafiltration (DEUF) to recover $\mathrm{Cu}^{2+}$ from aqueous solutions. In this process $\mathrm{Cu}^{2+} / \mathrm{EDA}$ core-PAMAM dendrimer complex was removed by UF from the aqueous solution. 
Table 3 shows the summary of the removal of heavy metals/ pollutant from water/wastewater by membranes.

\section{Ceramic membrane/materials for membrane adsorption}

In comparison to polymeric membranes, ceramic membranes are slower to foul, and can be regenerated using more extreme membrane performance recovery methods, which polymeric membranes are unable to handle due to thermal limitations of polymeric materials.

Ali et al. (2016) used ceramic membrane (with dimensions of $15 \times 15 \mathrm{~cm}$ and $2 \mathrm{~cm}$ thickness) filtration in removing three common heavy metals namely; $\mathrm{Pb}^{2+}, \mathrm{Cu}^{2+}$, and $\mathrm{Cd}^{2+}$ from water. The chemical analysis results showed high removal efficiency up to $99 \%$ for the concerned heavy metals. SEM image analysis showed the adsorbed metal ions were on sides of the internal pores of the ceramic membranes. Chooaksorn and Nitisoravut (2015) demonstrated that a novel method of simultaneous filtration and adsorption of heavy metal using chitosan coated ceramic membrane. Chitosan was introduced onto the ceramic membrane using a simple dip coating method. These coated membranes were then tested for nickel $(\mathrm{Ni})$ removal at various flow rates. At constant flow rate of $2.5 \mathrm{~mL} / \mathrm{min}$ and 10,15 and $20 \mathrm{mg}$ chitosan loadings, the amount of Ni removed were 89.0, 85.1 , and $74.2 \mathrm{mg} / \mathrm{g}$ chitosan, respectively. When the flow rate was doubled, the amount of Ni removed became 123.0, 113.8 , and $100.6 \mathrm{mg} / \mathrm{g}$ chitosan, respectively. The amount of Ni removed increased with an increase in flow rate, but decreased with an increase in the amount of chitosan loading, indicating that for the adsorption takes place mainly on the surface of chitosan film which, in turn, is controlled by surface area of the membrane. The adsorption kinetics can be well described using the Thomas model. Ahmad et al. (2012) used calcium carbonate as adsorbent the removal of $\mathrm{Zn}^{2+}, \mathrm{Cr}^{3+}, \mathrm{Pb}^{2+}, \mathrm{Cd}^{2+}, \mathrm{Cu}^{2+}$ and $\mathrm{Fe}^{3+}$.

Azamat et al. (2014) using molecular dynamics simulations for the separation of zinc ions as a heavy metal from water using boron nitride (BN) nanotubes embedded in a silicon-nitride membrane. It was revealed that that the $(7,7)$ and $(8,8) \mathrm{BN}$ nanotubes were exclusively selective of ions. The $(7,7) \mathrm{BN}$ nanotube selectively conducted $\mathrm{Zn}^{2+}$ ions, while the $(8,8) \mathrm{BN}$ nanotube selectively conducted $\mathrm{Cl}^{-}$ions. It was also reported that the passage of ions through nanotubes was related to the diameter of the $\mathrm{BN}$ nanotubes.

Sabo et al. (2015) described a hybrid membrane processes for the removal of metal ions from water. This method includes two processes: adsorption of metal ions on the natural zeolite and microfiltration of zeolite suspension through ceramic membrane. Experiments were carried out using model solutions containing $\mathrm{Cu}^{2+}$ ions [from $\mathrm{CuSO}_{4} \cdot 5 \mathrm{H}_{2} \mathrm{O}$ and $\mathrm{Cu}\left(\mathrm{NO}_{3}\right)_{2} \cdot 3 \mathrm{H}_{2} \mathrm{O}$ ] and $\mathrm{Zn}^{2+}$ ions [from $\mathrm{ZnSO}_{4} \cdot 7 \mathrm{H}_{2} \mathrm{O}$ and
$\left.\mathrm{Zn}\left(\mathrm{NO}_{3}\right)_{2} \cdot 6 \mathrm{H}_{2} \mathrm{O}\right]$. According to the results of the adsorption experiments zeolite adsorbed the nitrates ions (adsorption capacity of 1.48 and $1.49 \mathrm{mg} / \mathrm{g}$, for $\mathrm{Cu}^{2+}$ and $\mathrm{Zn}^{2+}$, respectively) better than the sulfate ions $(0.34$ and $0.85 \mathrm{mg} / \mathrm{g}$, for $\mathrm{Cu}^{2+}$ and $\mathrm{Zn}^{2+}$, respectively). Due to the better adsorption capacities of zeolite for ions derived from nitrates, further experiments were made from chemicals $\mathrm{Cu}\left(\mathrm{NO}_{3}\right)_{2} \cdot 3 \mathrm{H}_{2} \mathrm{O}$ and $\mathrm{Zn}\left(\mathrm{NO}_{3}\right)_{2} \cdot 6 \mathrm{H}_{2} \mathrm{O}$.

Chougui et al. (2014) designed a new type of a doublelayer ceramic membrane (ADLS) for the filtration of wastewater. New membrane contains a barrier layer (functional layer on a support (substrate) (with pore size of about $10 \mathrm{~nm}$ ). The performance of these membranes towards flux and retention rates was very high and suitable for ultrafiltration applications such as separation of dyes and heavy metals (Cd and Zn) from water. Bernat et al. (2007) used ceramic UF membrane for the separation of iron(II) and iron(III), copper(II) and chromium(III) from aqueous solution. It was suggested by Brenat et al. that there was a possibility of interaction between metallic species and membrane material.

Moayyeri et al. (2013) used bio-ceramic absorbers of hydroxy-apatite microparticles for the removal of heavy metals (lead, cadmium, zinc, nickel and iron) from water. Due to hydroxy-apatite microparticles as absorbers in ceramic, the absorption percentage average of lead $(84.72 \%)$ was greater than that of cadmium (49.89\%), zinc $(72.90 \%)$, iron (74.50\%) and nickel (79.25\%). From these results, it seems that hydroxy-apatite microparticles can be used as filler in polymeric embraces for the removal of heavy metals from waste water. Table 4 shows the summary for heavy metal separation by ceramics membranes/material for the heavy metal separation.

\section{Hybrid processes that include membrane adsorption}

Mavrov et al. (2003) developed a new integrated process combining adsorption, membrane separation and flotation for the selective separation of heavy metals from wastewater. The process was divided into the following three stages:

1. Heavy metal bonding (adsorption) by a bonding agent.

2. Wastewater filtration to separate the loaded bonding agent by two variants: crossflow microfiltration for lowcontaminated wastewater (Fig. 5), or a hybrid process combining flotation and submerged microfiltration for highly contaminated wastewater (Fig. 6).

3. Bonding agent regeneration. Synthetic zeolite R selected as a bonding agent, was characterized and used for the separation of the zeolite loaded with metal.

Another hybrid process, membrane contactor, is not only combining an extraction and an absorption process but both 
Table 3 Summary of the removal of heavy metals/pollutant from water/wastewater by membranes

\begin{tabular}{|c|c|c|c|}
\hline Membrane & Removal of & From & References \\
\hline Natural and crosslinked chitosan & $\mathrm{Hg}$ & Aqueous solution & Vieira and Beppu (2005) \\
\hline $\mathrm{ZnA1}_{2} \mathrm{O}_{4}-\mathrm{TiO}_{2}$ UF membranes & $\mathrm{Cd}(\mathrm{II})$ and $\mathrm{Cr}(\mathrm{III})$ ions & Water & Saffaj et al. (2004) \\
\hline Anion exchange polymer & $\mathrm{Cu}^{2+}, \mathrm{Ni}^{2+}$ and $\mathrm{Cr}^{6+}$ & Wastewater from industries & Padmavathi et al. (2014) \\
\hline $\begin{array}{l}\text { Four membranes: LDPE-g-Sty/ } \\
\text { AAc, LDPE-g-Sty/AAm, PP-g- } \\
\text { Sty/AAc, PP-g- Sty/AAm }\end{array}$ & $\mathrm{U}, \mathrm{V}, \mathrm{Zr}, \mathrm{Mo}$ & Aqueous solution & Dessouki et al. (2000) \\
\hline Polyethylene graft copolymers & Phosphate & Aqueous solutions & Senna et al. (2013) \\
\hline $\begin{array}{l}\text { Chitosan-graft-polyacrylamide } \\
\text { semi-IPN hydrogels }\end{array}$ & $\mathrm{Hg}(\mathrm{II})$ & Aqueous solution & Saber-Samandari and Gazi (2013) \\
\hline Silica- and cellulose-based MF & $\mathrm{Pb}^{2+}, \mathrm{Cu}^{2+,}$ and $\mathrm{Cd}^{2+}$ & Drinking and industrial water & Ritchie et al. (1999) \\
\hline PAN/PET MF & $\begin{array}{l}\mathrm{Cr}^{6+}, \mathrm{Pb}^{2+}, \text { Escherichia coli (by } \\
\text { size extrusion), }\end{array}$ & Aqueous solution & Wang et al. (2013) \\
\hline $\begin{array}{l}\text { PTFE/ } \\
\text { hyperbranchedpoly(amidoamine) }\end{array}$ & $\mathrm{Cu}^{2+}$ & Aqueous solution & Yoo and Kwak (2013) \\
\hline DETA-PES-type affinity & Phosphate & Aqueous solution & Ritchie et al. (1999) \\
\hline $\begin{array}{l}\text { Glutaraldehyde-crosslinked Chi- } \\
\text { tosan }(\mathrm{CH})\end{array}$ & $\mathrm{Hg}^{2+}$ & Aqueous solution & Vieira and Beppu (2006) \\
\hline Nafion 117 & $\begin{array}{l}\mathrm{Ni}(\mathrm{II}), \mathrm{Co}(\mathrm{II}), \mathrm{Pb}(\mathrm{II}), \mathrm{Cu}(\mathrm{II}) \\
\mathrm{Ag}(\mathrm{I})\end{array}$ & Synthesized aqueous solutions & Senna et al. (2013) \\
\hline Chitosan/ $\gamma$ - cyclodextrin) & $\mathrm{Cd}^{2+}$ & Wastewater & $\begin{array}{l}\text { Muthulakshmi and Anuradha } \\
\text { (2015) }\end{array}$ \\
\hline Alignate & $\begin{array}{l}\mathrm{Ca}^{2+}, \mathrm{Mg}^{2+}, \mathrm{Pb}^{2+}, \mathrm{Cu}^{2+}, \mathrm{Zn}^{2+} \\
\mathrm{Ni}^{2+}\end{array}$ & & Fatin-Rouge et al. (2006) \\
\hline $\mathrm{CH} /$ nylon-based & $\mathrm{Cu}^{2+}$ & Water & He et al. (2008) \\
\hline CAP-active alumina MMMs & F ion & Water & Chatterjee and De (2014) \\
\hline PES/FMBO MMS & As(III) & Contaminated water solution & Gohari et al. (Gohari et al. 2013) \\
\hline Zr-based nanoparticle PSF HF & Arsenate & Arsenate contaminated water & He et al. (2014) \\
\hline CA-PVP & $\mathrm{Fe}^{3+}, \mathrm{Cu}^{2+}$ & Liquid phase & Krason and Pietrzak (2016) \\
\hline $\mathrm{Cr}(\mathrm{III})-\mathrm{PVA} / \mathrm{SA}$ & $\mathrm{Cr}(\mathrm{III})$ & Aqueous solution & Chen et al. (2010) \\
\hline \multicolumn{4}{|l|}{ Hybrid membrane } \\
\hline TMSPED & Sr ions & Stimulated radioactive wastewater & Gohari et al. (2013) \\
\hline Cation-exchange resin/PES & $\mathrm{Hg}^{2+}, \mathrm{Cu}^{2+}, \mathrm{Pb}^{2+}$ & Drinking water & Zheng et al. (2014) \\
\hline Cellulose/thiol dendrimer & $\mathrm{Cd}^{2+}, \mathrm{Hg}^{2+}, \mathrm{Pb}^{2+}$ & Heavy metal solutions & Algarra et al. (2014) \\
\hline $\begin{array}{l}\text { Polystyrene and polyHIPE/iron } \\
\text { hydroxides }\end{array}$ & As & Water & Katsoyiannis and Zouboulis (2002) \\
\hline $\begin{array}{l}\text { Poly(vinyl alcohol)/ } \\
\text { poly(ethyleneimine) }\end{array}$ & $\mathrm{Pb}^{2+}, \mathrm{Cd}^{2+}, \mathrm{Cu}^{2+}$ & Aqueous solutions & Bessbousse et al. (2008) \\
\hline $\begin{array}{l}\text { PAZ/UF membrane (Ca-activated } \\
\text { zeolites) }\end{array}$ & Phosphate & Aqueous solution & Hermassi et al. (2016) \\
\hline $\mathrm{ZnAl}_{2} \mathrm{O}_{4}-\mathrm{TiO}_{2} \mathrm{UF}$ & $\begin{array}{l}\mathrm{Cd}^{2+}, \mathrm{Cr}^{3+}, \mathrm{Pb}^{2+} \text {, methylene blue } \\
\text { and orange acid }\end{array}$ & Water & Saffaj et al. (2004) \\
\hline AC/PSF & $\mathrm{Cd}, \mathrm{Cr}, \mathrm{Ag}, \mathrm{Pb}$ & Synthetic wastewater & Said et al. (2015) \\
\hline $\mathrm{CH}-\mathrm{Fe}(\mathrm{III}) \mathrm{HF}$ & $\operatorname{As}(\mathrm{V})$ & Aqueous solutions & Dorraji et al. (2014) \\
\hline $\begin{array}{l}\text { Cellulose/alginic acid ion- } \\
\text { exchange membrane }\end{array}$ & $\mathrm{Cd}^{2+}, \mathrm{Sr}^{2+}$ & Aqueous solutions & Zhang et al. (1999) \\
\hline $\begin{array}{l}\text { UF membrane (cellulose acetate, } \\
\text { nanochitosan, and polyethylene } \\
\text { glycol) }\end{array}$ & $\mathrm{Cr}(\mathrm{VI})$ & Tannery effluent & Vinodhini and Sudha (2016) \\
\hline \multicolumn{4}{|l|}{ Other } \\
\hline $\begin{array}{l}\text { Polyethylenimine-grafted gelatin } \\
\text { sponge }\end{array}$ & $\mathrm{Cd}^{2+}, \mathrm{Pb}^{2+}$ & Irrigation waste water & Li et al. $(2016 a, b)$ \\
\hline Polypyrrole (PPy) based & $\mathrm{Cr}(\mathrm{VI}), \mathrm{Zn}(\mathrm{II})$, and $\mathrm{Pb}(\mathrm{II})$ & Waste water/aqueous solution & Mahmud et al. (2016) \\
\hline PEUF and DEUF technique & $\mathrm{Cu}^{2+}$ & Aqueous solution & Diallo et al. $(2004,2005)$ \\
\hline
\end{tabular}


Table 4 Summary for heavy metal separation by ceramics/ membranes material for the heavy metal separation

\begin{tabular}{llll}
\hline Membrane & Removal of & From & References \\
\hline $\begin{array}{l}\text { Silicon-nitride- } \\
\text { BN nanotubes }\end{array}$ & $\mathrm{Zn}^{2+}$ & Water & Azamat et al. (2014) \\
Ceramic & $\mathrm{Pb}^{2+}, \mathrm{Cu}^{2+}, \mathrm{Cd}^{2+}$ & Water & Ali et al. (2016) \\
Ceramic & $\mathrm{Cu}^{2+}, \mathrm{Zn}^{2+}$ & Water solution & Sabo et al. (2015) \\
$\mathrm{CH} /$ ceramic & $\mathrm{Ni}^{2+}$ & Aqueous solutions & Chooaksorn and Nitisoravut (2015) \\
ADLS & $\mathrm{Dyes}, \mathrm{Cd}, \mathrm{Zn}$ & Waste water & Chooaksorn and Nitisoravut (2015) \\
Ceramic UF & $\mathrm{Fe}(\mathrm{II}), \mathrm{Fe}(\mathrm{III}), \mathrm{Cu}(\mathrm{II}), \mathrm{Cr}(\mathrm{III})$ & Aqueous solutions & Bernat et al. (2007) \\
Bio-ceramic & $\mathrm{Pb}, \mathrm{Cd}, \mathrm{Zn}, \mathrm{Fe}, \mathrm{Ni}$ & Aqueous solutions & Moayyeri et al. (2013) \\
\hline
\end{tabular}

Fig. 5 The integrated processes combining metal bonding and separation by cross flow membrane filtration (for low-contaminated wastewater) (Mavrov et al. 2003)
Fig. 6 The integrated processes combining metal bonding and separation by a new hybrid process (for highly contaminated wastewater)
Bonding agents

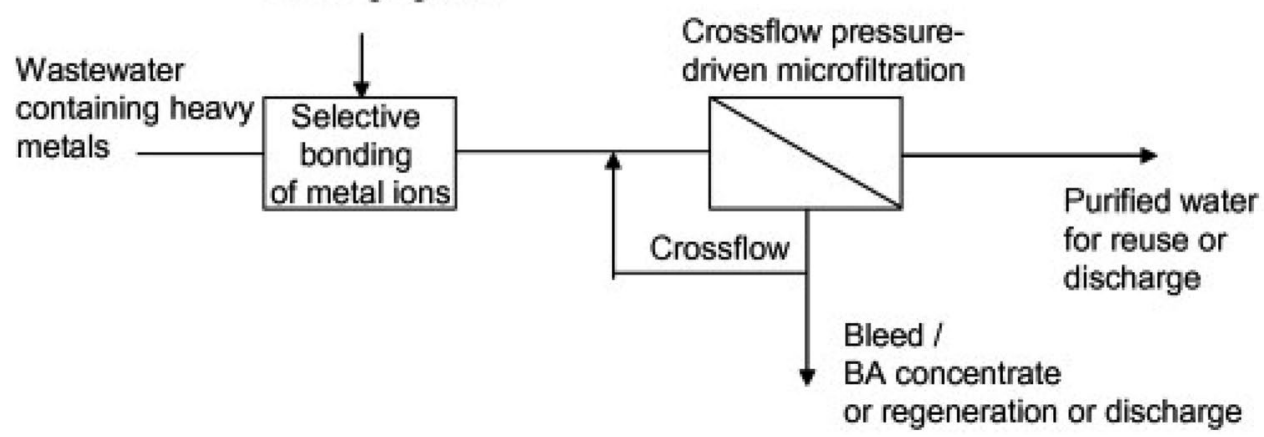

processes are fully integrated and incorporated into one piece of equipment to exploit the benefits of both technologies fully (Klaassen et al. 2008). It offers a flexible modular energy efficient device with a high specific surface area. It is important to note that the selection of the appropriate membrane depends on a number of factors such as the characteristics of the wastewater, the concentration of the heavy metals, $\mathrm{pH}$ and temperature. In addition, the membranes should be compatible with the feeding solution and cleaning agents to minimize surface fouling.

\section{Electrospun nanofibers}

It is reported that nanomaterials as sorbents (CNTs, nanometal or nanometal oxides, and other organic sorbents) are useful tools for heavy metal removal, due to their unique structure and surface characteristics (Wang et al. 2012). Nano materials have higher reactivity, larger surface contact and better disposal capability. Nanoparticles in the matrices of host material change the structures and properties of both nanomaterials and host matrices. As will be discussed later 
on, there are several examples of nanoparticles and nanomaterials that can be used for the treatment of water treatment, e.g., zeolites, carbon nanotubes (CNTs) self-assembled monolayers on mesoporous supports, biopolymers, singleenzyme nanoparticles, nanoparticles of zero valent iron (ZVI), among others (Yunus et al. 2012). Amin et al. (2014) discussed the possible applications of the nanoparticles/fibers for the removal of pollutants from water/wastewater.

Membranes fabricated from nanomaterials for removing heavy metal ions in wastewater should satisfy the following criterions:

1. The nanosorbents themselves should be nontoxic.

2. The sorbents present relatively high sorption capacities and selectivity to the low concentration of pollutants.

3. The adsorbed pollutant could be removed from the surface of the nano adsorbent easily.

4. The sorbents could be infinitely recycled.

Tian et al. (2011) studied cellulose acetate (CA) nonwoven membrane, prepared by electrospinning and surface modified with poly(methacrylic acid) (PMAA) using $\mathrm{Ce}^{4+}$ initiated radical graft copolymerization), for heavy metal ions $\left(\mathrm{Cu}^{2+}, \mathrm{Hg}^{2+}\right.$ and $\left.\mathrm{Cd}^{2+}\right)$ adsorption in water. It was observed that this membrane had quite high adsorption selectivity for $\mathrm{Hg}^{2+}$. The adsorbed metal ions can be easily de-adsorbed from the membrane surface using saturated ethylenedinitrilo tetraacetic acid solution, and can be re-used for the metal ion adsorption.

Ma et al. (2013) demonstrated that functional nanofibrous membranes fabricated by the electrospinning technology, can be used to remove heavy metal ions through adsorption from contaminated water. These membranes are considered for higher permeation flux and lower pressure drop performance than conventional microfiltration membranes. However, these membranes also possess a high surface-tovolume ratio and functionalizable surface that can remove toxic metal ions with a capability comparable to typical absorbents.

Yun et al. (2014) fabricated nanofibrous membrane from zein protein which is derived from maize. The zein nanofibrous membrane (ZNM) was prepared using $80 \%$ ethanol solution as a solvent. The membrane was used to separate $\mathrm{Cr}$ (VI)from water. It was suggested that $\mathrm{ZNM}$ would be an effective means of removing $\mathrm{Cr}(\mathrm{VI})$ from industrial wastewater.

Karim (2015) discussed the potentiality of PVA-Chitosan nanofiber membranes (NFs) in wastewater treatment processes especially for toxic metal removals. The kinetic studies indicated that the adsorption of $\mathrm{Pb}$ and $\mathrm{Cd}$ onto NFs best fit the pseudo-second order kinetic model. The equilibrium adsorption study revealed that the Langmuir model was the most appropriate to describe $\mathrm{Pb}$ and $\mathrm{Cd}$ adsorption behaviors on NFs. The monolayer maximum adsorption capacities of $\mathrm{Pb}$ and $\mathrm{Cd}$ were found to be 199 and $68 \mathrm{mg} / \mathrm{g}$, respectively. Therefore, the NFs exhibited great potential for the removal of $\mathrm{Pb}$ and $\mathrm{Cd}$ from wastewater in engineering practices.

Liu et al. (2015) fabricated electrospun nanofibrous microfiltration membrane having positive surface charges and capable of removing $\mathrm{Cr}(\mathrm{VI})$ from contaminated water. Polyacrylonitrile (PAN) was electrospun into a nanofibrous scaffold with an average fiber diameter of about $200 \mathrm{~nm}$. Polyvinylamine (PVAm), a positively charged polymer, was grafted onto the nanofibrous scaffold through cross-linking reaction by glutaraldehyde. It was found that at $\mathrm{pH} 6$, the PAN-g-PVAm membrane showed almost two times higher adsorption capacity than activated carbons, and about 20 times higher than some synthetic activated carbons. The PAN-g-PVAm membrane also exhibited excellent $\mathrm{Cr}$ (VI) adsorption capability in a dynamic filtration process.

Yang et al. (2015a) prepared thiol modified natural polysaccharide chitin nanofibers and used as an absorbent material for arsenic [As(III)] removal. The arsenic adsorption performance of thiol-modified chitin nanofibers was evaluated under different $\mathrm{pH}$ conditions and at different metal ion concentrations, where the maximum adsorption capacity was found to be $149 \mathrm{mg} / \mathrm{g}$ at pH 7.0 using the Langmuir model.

Bozorgpour et al. (2016) studied the removal of nitrate and phosphate via chitosan $/ \mathrm{Al}_{2} \mathrm{O}_{3} / \mathrm{Fe}_{3} \mathrm{O}_{4}$ composite nanofibrous adsorbent, prepared by electrospinning process, and the results were compared with chitosan $/ \mathrm{Al}_{2} \mathrm{O}_{3} / \mathrm{Fe}_{3} \mathrm{O}_{4}$ composite bead adsorbent. The Box-Behnken design was used to investigate the interaction effects of adsorbent dosage, nitrate and phosphate initial concentrations on the nitrate and phosphate removal efficiency. The obtained results revealed the higher potential of chitosan $/ \mathrm{Al}_{2} \mathrm{O}_{3} / \mathrm{Fe}_{3} \mathrm{O}_{4}$ composite nanofibers for nitrate and phosphate compared with chitosan $/ \mathrm{Al}_{2} \mathrm{O}_{3} / \mathrm{Fe}_{3} \mathrm{O}_{4}$ composite beads.

$\mathrm{Wu}$ et al. (2010) fabricated mesoporous poly(vinyl alcohol) $/ \mathrm{SiO}_{2}$ composite nanofiber membranes functionalized with mercapton groups with diameters of 300-500 nm have been fabricated by a sol gel electrospinning process and reported that these membranes were highly effective at absorbing $\mathrm{Cu}(\mathrm{II})$ ions from waste water.

Li et al. (2016a, b) fabricated chitosan $(\mathrm{CH})$ nanofiber (NFB) membranes with different fiber deposition densities on polyester scrim (PET scrim) by electrospinning. These composite nanofiber membranes were used for the study of dynamic adsorption capacity for $\mathrm{Cr}(\mathrm{VI})$ ions. The maximum bed loading capacity for $1 \mathrm{mg} / \mathrm{L} \mathrm{Cr}(\mathrm{VI})$ filtration at the breakthrough point was found to be $16.5 \mathrm{mg}$ chromium/g-chitosan, higher than the static adsorption capacity of $11.0 \mathrm{mg}$-chromium/g-chitosan using nanofiber mats, indicating the membranes' better potential for dynamic adsorption. 
Shooto et al. (2016) fabricated nanofibers via electrospun, from polyvinyl alcohol (PVA) and PVA incorporated with metal (Co) organic framework (PVA-Co-MOF), and investigated the ability of these fibers to remove $\mathrm{Pb}$ (II) ions from water. It was reported that the sorption of $\mathrm{Pb}^{2+}$ ions on PVA-Co-MOF) were twice as compared to the PVA nanofiber. Habiba et al. (2017) prepared chitosan/PVA/zeolite nanofibrous composite membrane by electrospinning method. The adsorption ability of nanofibrous membrane was studied over $\mathrm{Cr}^{6+}, \mathrm{Fe}^{3+}$, and $\mathrm{Ni}^{2+}$ ions. The absorption capacity of chitosan/(polyvinyl alcohol)/zeolite membrane for $\mathrm{Cr}^{6+}, \mathrm{Fe}^{3+}$ and $\mathrm{Ni}^{2+}$ were $0.17,0.11$ and $0.03 \mathrm{mmol} / \mathrm{gm}$ under experimental conditions, respectively. Aliabadi (2016) used chitosan/cobalt ferrite nanofibers for the removal of $\mathrm{Pb}^{2+}$ and $\mathrm{Cr}^{6+}$ from water. Haider and Park (2009) studied the removal of $\mathrm{Cu}(\mathrm{II})$ and $\mathrm{Pb}$ (II) ions from aqueous solution using electrospun chitosan nanofiber mats, neutralized with potassium carbonate, via adsorption. It was reported by Haider and Park that chitosan nanofiber mats had good erosion stability in water and high adsorption affinity for metal ions in an aqueous solution. Chitosan electrospun nanofiber mats can be applied to filter out (or neutralize) toxic metal ions and microbes without losing their original chitosan properties such as biocompatibility, hydrophilicity, bioactivity, non-antigenicity, and non-toxicity due to their high adsorption capacity. Table 5 shows the summary of electrospun nanofiber/membrane used for the removal of heavy metals/pollutants from water/wastewater.

\section{Nanosized metal oxides (NMOs)/nanomaterial}

Due to the high surface area of nanosized metal oxides (NMOs), including nanosized ferric oxides, manganese oxides, aluminum oxides titanium oxides, magnesium oxides and cerium oxides, have specific affinity for heavy metal removal via adsorption from aqueous systems (Hua et al. 2012). Kim and der Bruggen (2010) discussed the role of engineered nanomaterials (titania, alumina, silica, silver and many others) in (pressure driven) membrane technology for water treatment to be applied in drinking water production and wastewater recycling. Hybrid membranes comprising inorganic fillers in a polymeric matrix are common. The fillers can be used for separation improvement. Amin et al. (2014) discussed the possible applications of the nanoparticles/fibers for the removal of pollutants from water/wastewater. The most promising nanomaterials and applications are highlighted in Table 6.

So far, a variety of nanomaterials such as carbon nanotubes, carbon-based material composites, graphene, nano metal or metal oxides, and polymeric sorbents have been studied in the removal of heavy metal ions from aqueous solutions, and the results indicate that these nanomaterials show high adsorption capacity (Wang et al. 2012). Adsorbents of heavy metal ions can range cheap bio-waste recycling to functional nanomaterials (Yoo and Kwak 2013). Nanomaterials from bio-waste adsorbents, contains functional groups, such as amine, carboxyl, and thiol groups, which can form co-ordinate bonds with heavy metal ions by donation of lone-pair electrons. These materials allow easy switching between the trapping and release of heavy metal ions by adjusting the $\mathrm{pH}$ from neutral to acid conditions. Most combined approaches using MF/UF membranes and adsorbents have attempted to utilize this advantage. Ghaemi et al. (2011) used absorption technique for strontium and barium removal from aqueous solution using

Table 5 Summary of electrospun nanofiber/membrane used for the removal of heavy metals/pollutants from water/wastewater

\begin{tabular}{|c|c|c|c|}
\hline Electrospun nanofiber/membrane & Removal of & From & References \\
\hline CA/(PMAA) & $\mathrm{Cu}^{2+}, \mathrm{Hg}^{2+}$ and $\mathrm{Cd}^{2+}$ & Water & Tian et al. (2011) \\
\hline PVA-Chitosan & $\mathrm{Pb}, \mathrm{Cd}$ & Wastewater & Karim (2015) \\
\hline PAN and PVAm & $\mathrm{Cr}(\mathrm{VI})$ & Synthetic contaminated water & Liu et al. (2015) \\
\hline Chitosan $/ \mathrm{Al}_{2} \mathrm{O}_{3} / \mathrm{Fe}_{3} \mathrm{O}_{4}$ & Nitrate and copper & Aqueous solution & Bozorgpour et al. (2016) \\
\hline $\begin{array}{l}\text { PAN/PET/containing infused ultra-fine func- } \\
\text { tional cellulose nanofibers }\end{array}$ & Escherichia coli, $\mathrm{Cr}(\mathrm{VI}), \mathrm{Pb}(\mathrm{II})$ & Metal ion solutions & Wang et al. (2013) \\
\hline Chitosan/PVA/zeolite & $\mathrm{Cr}(\mathrm{VI}), \mathrm{Fe}(\mathrm{III})$, and $\mathrm{Ni}(\mathrm{II})$ ions & $\begin{array}{l}\text { Potassium dichromate, nickel, } \\
\text { chloride, and iron chloride } \\
\text { solution }\end{array}$ & Habiba et al. (2017) \\
\hline PVA and PVA-Co-MOF & $\mathrm{Pb}(\mathrm{II})$ & Aqueous solution & Shooto et al. (2016) \\
\hline Poly(vinyl alcohol)/SiO 2 & $\mathrm{Cu}(\mathrm{II})$ & Wastewater & Wu et al. (2010) \\
\hline CH NFB/PET scrim & $\mathrm{Cr}(\mathrm{VI})$ & Water containing $\mathrm{Cr}$ ions (VI) & Li et al. $(2016 a, b)$ \\
\hline Chitosan/cobalt ferrite & $\mathrm{Pb}(\mathrm{II}), \mathrm{Cr}(\mathrm{VI})$ & Aqueous solution & Aliabadi (2016) \\
\hline Chitosan mats & $\mathrm{Cu}(\mathrm{II})$ and $\mathrm{Pb}(\mathrm{II})$ ions & Aqueous solution & Haider and Park (2009) \\
\hline Thiol modified natural polysaccharide chitin & $\mathrm{As}(\mathrm{III})$ & Aqueous solution & Yang et al. (2015a) \\
\hline ZNM & $\mathrm{Cr}(\mathrm{VI})$ & Aqueous solution & Yun et al. (2014) \\
\hline
\end{tabular}


Table 6 Overview of the types of nanomaterials applied for water and wastewater technologies (Gehrke et al. 2015)

\begin{tabular}{|c|c|c|}
\hline Nanomaterial & Properties & Applications \\
\hline Nanoadsorbents & $\begin{array}{l}\text { + high specific surface, higher adsorption rates, } \\
\text { small footprint } \\
\text { - high production costs }\end{array}$ & $\begin{array}{l}\text { Point-of-use, removal of organics, heavy metals, } \\
\text { bacteria }\end{array}$ \\
\hline Nanometals and nanometal oxides & $\begin{array}{l}\text { + short intraparticle diffusion distance compressible, } \\
\text { abrasion-resistant, magnetic } \\
\text { + photocatalytic }\left(\mathrm{WO}_{3}, \mathrm{TiO}_{2}\right) \\
\text { - less reusable }\end{array}$ & $\begin{array}{l}\text { Removal of heavy metals (arsenic) and radionu- } \\
\text { clides, media filters, slurry reactors, powders, } \\
\text { pellets }\end{array}$ \\
\hline Membranes and membrane processes & $\begin{array}{l}\text { + reliable, largely automated process } \\
\text { - relative high energy demand }\end{array}$ & $\begin{array}{l}\text { All fields of water and waste-water treatment } \\
\text { processes }\end{array}$ \\
\hline
\end{tabular}

dolomite powder. The results showed that the adsorption for both ions was feasible and exothermic.

Tu et al. (2016) claimed that for the first time they used composite magnetic nanoparticles $\left(\mathrm{CuFe}_{2} \mathrm{O}_{4}\right)$ which were synthesized from industrial sludge by acid leaching, chemical exchange, and ferrite processes for the adsorption of $\mathrm{Sr}$ from seawater. Further, Tu et al. also claimed that these composite magnetic nanoparticles can be used for the removal of radiogenic ${ }^{90} \mathrm{Sr}$ nuclide in seawater that was released after the 3/11 earthquake offshore of Japan.

\section{Polymeric/inorganic nanoparticle}

As polymer nanoparticles have amphiphilic properties, it can be used for water treatment. Each molecule has hydrophobic and hydrophilic parts. When water is available, the polymer will form a polymer cell with a diameter of several nanometers inside the hydrophobic part, while the hydrophilic part is outside. On polymer nanoparticles, crosslink occurs prior to the aggregation of particles so that their stability is maintained. Amphiphilic polyurethane (APU) nanoparticles have good prospects as a remediation agent (Yunus et al. 2012).

Cellulose nanomaterials $(\mathrm{CN})$ membranes are also used for water filtrations. On comparing with CNTs in terms of physical and chemical properties, production costs, use and disposal, it seems that the potential of cellulose nanomaterials as a sustainable replacement for CNTs in water treatment technologies is high (Carpenter et al. 2015; Yunus et al. 2012).

Carbon-based nanosorbents proved as effective adsorbents for the removal of cadmium ions from water (Kumar et al. 2015). Taman et al. (2015) used copper oxide nanoparticles for the removal of heavy metals [Cd(II) and $\mathrm{Fe}(\mathrm{III})]$ from wastewater via adsorption process. Predescu and Nicolae (2012) synthesized a nano-composite particle from $\gamma-\mathrm{Fe}_{2} \mathrm{O}_{3}$ with AMBERLITE cationic exchange resin and reported that the nano-composite material had remarkable adsorption efficiency in the removal of some toxic metal ions as $\mathrm{Zn}, \mathrm{Cu}, \mathrm{Cr}$. Nassar et al. (2014) used magnetic nanoparticles $\left(\gamma-\mathrm{Fe}_{2} \mathrm{O}_{3}\right)$ as an adsorbent for phenol and olive mill wastewater (OMW) treatment. Beside these, other heavy metals $\left(\mathrm{Fe}^{3+}, \mathrm{Cr}^{2+}, \mathrm{Cu}^{2+}, \mathrm{Ca}^{2+}\right)$ can be removed from OMW.

Liu et al. (2008) developed humic acid coated $\mathrm{Fe}_{3} \mathrm{O}_{4}$ nanoparticles $\left(\mathrm{Fe}_{3} \mathrm{O}_{4} / \mathrm{HA}\right)$ for the removal of toxic $\mathrm{Hg}$ (II), $\mathrm{Pb}(\mathrm{II}), \mathrm{Cd}(\mathrm{II})$, and $\mathrm{Cu}(\mathrm{II})$ from water. $\mathrm{The} \mathrm{Fe}_{3} \mathrm{O}_{4} / \mathrm{HA}$ was able to remove over $99 \%$ of $\mathrm{Hg}$ (II) and $\mathrm{Pb}$ (II) and over $95 \%$ of $\mathrm{Cu}$ (II) and $\mathrm{Cd}(\mathrm{II})$ in natural and tap water at optimized pH. Pang et al. (2011) reported that polyethylenimine (PEI) grafted magnetic porous adsorbent $\left(\mathrm{Fe}_{3} \mathrm{O}_{4}\right)$ had highly effective adsorption of heavy metals $\left(\mathrm{Cu}^{2+}, \mathrm{Zn}^{2+}, \mathrm{Cd}^{2+}\right)$. Carboxymethyl- $\beta$-cyclodextrin (CM- $\beta-\mathrm{CD}$ ) polymer modified $\mathrm{Fe}_{3} \mathrm{O}_{4}$ nanoparticles (CD poly-MNPs) was used for removal of $\mathrm{Pb}^{2+}, \mathrm{Cd}^{2+}$ and $\mathrm{Ni}^{2+}$. The maximum adsorption capacity was up to $157.81,138.84$ and $105.26 \mathrm{mg} / \mathrm{g}$ for $\mathrm{Cu}^{2+}, \mathrm{Zn}^{2+}$ and $\mathrm{Cd}^{2+}$.

It was revealed by Badruddoza et al. (2013) that CD polyMNPs [carboxymethyl- $\beta$-cyclodextrin (CM- $\beta$-CD) polymer modified $\mathrm{Fe}_{3} \mathrm{O}_{4}$ nanoparticles] preferentially adsorb $\mathrm{Pb}^{2+}$ ions with an affinity order:

$\mathrm{Pb}^{2+}>>\mathrm{Cd}^{2+}>\mathrm{Ni}^{2+}$,

$\mathrm{Fe}_{3} \mathrm{O}_{4}$ magnetic nanoparticles, synthesized by co-precipitation method, were used for the water treatment containing heavy metal ions [Pb(II), $\mathrm{Cu}(\mathrm{II}), \mathrm{Zn}(\mathrm{II})$ and $\mathrm{Mn}(\mathrm{II})]$ by Giraldo et al. (2013). The adsorption capacity of $\mathrm{Fe}_{3} \mathrm{O}_{4}$ nanoparticles was maximum for $\mathrm{Pb}$ (II) and minimum for $\mathrm{Mn}$ (II).

Mahdavi et al. (2012) investigated the removal of $\mathrm{Cd}^{2+}$, $\mathrm{Cu}^{2+}, \mathrm{Ni}^{2+}$, and $\mathrm{Pb}^{2+}$ from aqueous solutions with novel nanoparticle sorbents $\left(\mathrm{Fe}_{3} \mathrm{O}_{4}, \mathrm{ZnO}\right.$ and $\left.\mathrm{CuO}\right)$. Following order was determined for single component solutions: $\mathrm{Cd}^{2+}>\mathrm{Pb}^{2+}>\mathrm{Cu}^{2+}>\mathrm{Ni}^{2+}$, while for multiple component solutions: $\mathrm{Pb}^{2+}>\mathrm{Cu}^{2+}>\mathrm{Cd}^{2+}>\mathrm{Ni}^{2+}$ by all the three nanoparticles.

Nanostructured graphite oxide, silica/graphite oxide composites and silica nanoparticles were investigated for the removal of the heavy metal ions from aqueous solutions by a batch adsorption method (Sheet et al. 2014). The results 
revealed that the adsorption of heavy metals by nanostructured graphite oxide was observed in the following order: nickel $>$ zinc $>$ lead $>$ cadmium $>$ chromium.

Vélez et al. (2016) used iron oxide nanoparticles (IOPNs) which were stabilized with Aloe Vera for mercury removal from waste water. Mercury removal more than $85 \%$ was achieved (70\% average), using low concentrations of IOPNs solution. Table 7 shows the summary of the nanoparticles used for the removal of heavy metals from water/waste water.

\section{Zeolites}

The use of natural zeolites in wastewater treatment is one of the oldest and the most perspective areas of their application. Zeolites are a naturally occurring crystalline aluminosilicates consisting of a framework of tetrahedral molecules, linked with each other by shared oxygen atoms and its adsorption properties are due to its ion-exchange capabilities. Zeolite materials allow an introduction of new functional groups through several processes of modification, improving substantially its activity and selectivity on the removal of several substances. Many authors showed the use of modified natural zeolite on environmental applications, mainly anions uptake from effluents by adsorption processes (Oliveira and Rubio 2007). Ibrahimi and Sayyadi (2015) discussed the different parameters affecting the removal process of heavy metals and their individual impact on adsorption by zeolites including the main mechanism based on ion exchange.

Jiménez-Castañeda and Medina (2017) discussed the application of modified zeolites and clays for the removal of heavy metals from water. Zanin et al. (2017) studied clinoptilolite zeolite (CL) as adsorbent for removal of heavy metals $[\mathrm{Cu}(\mathrm{II}), \mathrm{Cr}(\mathrm{III}), \mathrm{Fe}(\mathrm{III})]$ in wastewater from the graphic industry, and reported that zeolite selectivity followed the order $\mathrm{Fe}>\mathrm{Cr}>\mathrm{Cu}$. $\mathrm{He}$ et al. (2016) reported that zeolite, synthesized from coal fly ash by a fusion method, could be used as an alternative adsorbent for the removal of heavy metal ions $\left(\mathrm{Pb}^{2+}, \mathrm{Cd}^{2+}, \mathrm{Cu}^{2+}, \mathrm{Ni}^{2+}, \mathrm{Mn}^{2+}\right)$ from industrial wastewater. The maximum adsorption capacity and the distribution coefficients exhibited the same sequence for $\mathrm{Pb}^{2+}>\mathrm{Cu}^{2+}>\mathrm{Cd}^{2+}>\mathrm{Ni}^{2+}>\mathrm{Mn}^{2+}$ in both single- and multi- heavy metal systems.

Ouki and Kavannagh (1997) studied two zeolites (clinoptilolite and chabazite) with respect to their selectivity and removal performance for the treatment of effluents contaminated with mixed heavy metals, namely $\mathrm{Pb}, \mathrm{Cd}, \mathrm{Cu}, \mathrm{Zn}, \mathrm{Cr}$, $\mathrm{Ni}$ and Co. The selectivity sequences for clinoptilolite and chabazite are summarized as follows: chabazite $(\mathrm{Pb}>\mathrm{Cd}$ $>\mathrm{Zn}>\mathrm{Co}>\mathrm{Cu}>\mathrm{Ni}>\mathrm{Cr})$; and clinoptilolite $(\mathrm{Pb}>\mathrm{Cu}$ $>\mathrm{Cd}>\mathrm{Zn}>\mathrm{Cr}>\mathrm{Co}>\mathrm{Ni}$ ). Wingenfelder et al. (2015) investigated the removal of $\mathrm{Fe}, \mathrm{Pb}, \mathrm{Cd}$, and $\mathrm{Zn}$ from synthetic mine waters by a natural zeolite. Zamzow et al. (1990) studied the removal of heavy metals from wastewater using clinoptilolite, and reported the selectivity of the heavy metals be as follows:

$$
\begin{aligned}
& \mathrm{Pb}(\mathrm{II})>\mathrm{Cd} \text { (II) }>\mathrm{Cu}(\mathrm{II})>\mathrm{Co}(\mathrm{II})>\mathrm{Cr}(\mathrm{III}) \\
& \quad>\mathrm{Zn}(\mathrm{II})>\mathrm{Ni}(\mathrm{II})>\mathrm{Hg}(\mathrm{II}),
\end{aligned}
$$

Taamneh and Sharadqah (2016) used natural Jordanian zeolite (NJ) as an adsorbent for removing cadmium and copper ion from aqueous solution and claimed that NJ zeolite is practical adsorbent for removing cadmium and copper ion metal.

Yurekli (2016) investigated the adsorption and the filtration processes together by a zeolite nanoparticle impregnated polysulfone (PSF) membrane to remove the lead and

\begin{tabular}{|c|c|c|c|}
\hline Material (nanoparticles) & Removal of & From & References \\
\hline Copper oxide & $\mathrm{Cd}(\mathrm{II})$ and $\mathrm{Fe}(\mathrm{III})$ & Wastewater & Taman et al. (2015) \\
\hline Carbon-based & $\mathrm{Cd}$ & Water & Kumar et al. (2015) \\
\hline $\mathrm{CuFe}_{2} \mathrm{O}_{4}$ & $\mathrm{Sr}\left(\right.$ may be $\left.{ }^{90} \mathrm{Sr}\right)$ & Sea water & Tu et al. (2016) \\
\hline Dolomite powder & $\mathrm{Ba}^{2+}, \mathrm{Sr}^{2+}$ & Aqueous solutions & Ghaemi et al. (2011) \\
\hline$\gamma-\mathrm{Fe}_{2} \mathrm{O}_{3} /$ resin & $\mathrm{Zn}, \mathrm{Cu}, \mathrm{Cr}$. & Wastewater & Predescu and Nicolae (2012) \\
\hline$\gamma-\mathrm{Fe}_{2} \mathrm{O}_{3}$ & $\begin{array}{l}\text { Dephhenolization, } \mathrm{Fe}^{3+}, \mathrm{Cr}^{2+}, \mathrm{Cu}^{2+} \text {, } \\
\mathrm{Ca}^{2+}\end{array}$ & Olive Mill waste water & Nassar et al. (2014) \\
\hline $\mathrm{Fe}_{3} \mathrm{O}_{4} / \mathrm{HA}$ & $\mathrm{Hg}^{2+}, \mathrm{Pb}^{2+}, \mathrm{Cd}^{2+}, \mathrm{Cu}^{2+}$ & Water & Liu et al. (2008) \\
\hline $\mathrm{Fe}_{3} \mathrm{O}_{4} / \mathrm{PE}$ & $\mathrm{Cu}^{2+}, \mathrm{Zn}^{2+}, \mathrm{Cd}^{2+}$ & Multi metal solution & Pang et al. (2011) \\
\hline Graphite oxide & $\mathrm{Ni}, \mathrm{Zn}, \mathrm{Pb}, \mathrm{Cd}, \mathrm{Cr}$ & Aqueous solutions & Sheet et al. (2014) \\
\hline CD poly-MNPs & $\mathrm{Pb}^{2+}, \mathrm{Cd}^{2+}, \mathrm{Ni}^{2+}$ & Industrial wastewater & Badruddoza et al. (2013) \\
\hline $\mathrm{Fe}_{3} \mathrm{O}_{4}$ & $\mathrm{~Pb}(\mathrm{II}), \mathrm{Cu}(\mathrm{II}), \mathrm{Zn}(\mathrm{II}), \mathrm{Mn}(\mathrm{II})$ & Aqueous solutions & Giraldo et al. (2013) \\
\hline IOPNs (stabilized with Aloe Vera) & $\mathrm{Hg}(\mathrm{II})$ & Waste water & Vélez et al. (2016) \\
\hline $\mathrm{Fe}_{3} \mathrm{O}_{4}, \mathrm{ZnO}$, and $\mathrm{CuO}$ & $\mathrm{Cd}^{2+}, \mathrm{Cu}^{2+}, \mathrm{Ni}^{2+}, \mathrm{Pb}^{2+}$ & Aqueous solutions & Mahdavi et al. (2012) \\
\hline
\end{tabular}

Table 7 Summary of the nanoparticles used for the removal of heavy metals from water/waste water 
the nickel cations from synthetically prepared solutions. The maximum sorption capacity of the hybrid membrane for the lead and nickel ions was measured as 682 and $122 \mathrm{mg} / \mathrm{g}$, respectively.

Tijani et al. (2013) studied the NaA zeolite membranes for heavy metal removal from synthesized solutions and reported that the removal of $\mathrm{Pb}(\mathrm{II}), \mathrm{Zn}$ (II) and $\mathrm{Cr}(\mathrm{VI})$ showed, respectively, the rejection of 99,99 and $12 \%$ after $1 \mathrm{~h}$ of filtration at 7 bars of $\mathrm{N}_{2}$ and at ambient temperature. Zeolites are used as filler in polymers (composite membranes) for the sedation of heavy metals from water/waste water as discussed earlier. Table 8 shows the summary of the use of zeolites for water treatment by adsorption.

\section{Carbon nanotubes (CNTs)}

CNTs have been proven to possess great potential for removing heavy metal ions such as $\mathrm{Pb}, \mathrm{Cd}, \mathrm{Cr}, \mathrm{Cu}, \mathrm{Ni}$ from waste water (Fu and Wang 2011). Ma et al. (2017) explored the application of CNTs-based composite membranes for water treatment. CNTs are divided into two types:

1. Single-walled CNTs (SWCNTs).

2. Multi-walled CNTs (MWCNTs).

The mechanisms by which the metal ions are sorbed onto CNTs are very complicated and appear attributable to electrostatic attraction, sorption-precipitation and chemical interaction between the metal ions and the surface functional groups of CNTs (Rao et al. 2007). The mechanisms by which the metal ions are sorbed onto CNTs are very complicated. It seems that electrostatic attraction, sorption-precipitation and chemical interaction take part.

The sorption capacities of metal ions by raw CNTs are very low, but significantly increase after being oxidized by $\mathrm{HNO}_{3}, \mathrm{NaClO}$ and $\mathrm{KMnO}_{4}$ solutions. The removal efficiency for metal ions by CNTs was observed in a range 10-80\%, which could be improved to nearly $100 \%$ by selectively functionalizing CNTs with organic ligands (Yu et al. 2014). Khan et al. (2016) described the adsorption behavior and use of CNTs including the effects of surface modification on the adsorption behavior and subsequent heavy metal removal. In review, Sadegh et al. (2016) discussed recent developments and applications of CNTs for heavy metal ions removal from polluted water and their advantages as adsorbents in the treatment of polluted aqueous solutions. Mubarak et al. (2014) discussed the use of CNTs as adsorbent for heavy metals from industrial wastewater and summaries of liquid pollutant purification. CNTs have great potential as a novel type of adsorbent due to their unique properties such as chemical stability, mechanical and thermal stability, and the high surface area.

Carbon nanotubes have been proved effective alternatives for the removal of metallic pollutants from aqueous solutions (Sharma et al. 2009). Due to its importance from an environmental viewpoint, special emphasis has been given to the removal of the metals $\mathrm{Cr}, \mathrm{Cd}, \mathrm{Hg}, \mathrm{Zn}$, $\mathrm{As}$, and $\mathrm{Cu}$. Wang et al. (2007) investigated acidified multiwalled carbon nanotubes (MWCNTs) for the heavy metal adsorption using $\mathrm{Pb}^{2+}$ as a model. It was revealed that the oxygenous functional groups can be formed on MWCNTs after MWCNTs were treated by concentrated nitric acid. The oxygenous functional groups play an important role in $\mathrm{Pb}^{2+}$ adsorption to form chemical complex, which accounts for $75.3 \%$ of all the $\mathrm{Pb}^{2+}$ adsorption capacity. The $\mathrm{Pb}$ in the form of $\mathrm{PbO}$, $\mathrm{Pb}(\mathrm{OH})_{2}$, and $\mathrm{PbCO}_{3}$ adsorbed on the surface of the acidified MWCNTs is only $3.4 \%$ of the total $\mathrm{Pb}^{2+}$ adsorption capacity.

Pillay et al. (2009) studied the adsorption capabilities for the removal of parts per billion levels ( $\mathrm{ppb}$ ) of hexavalent chromium by three adsorbents namely activated carbon, functionalized multi-walled carbon nanotubes (MWCNTs) and unfunctionalized multi-walled carbon nanotubes. Highest adsorption capability with up to $98 \%$

Table 8 Summary of the use of zeolites for water treatment by adsorption

\begin{tabular}{llll}
\hline Zeolite & Removal of & From & References \\
\hline Modified zeolites and clays & Heavy metals & Water & Jiménez-Castañeda and Medina (2017) \\
Cinoptilolite zeolite & $\mathrm{Cu}(\mathrm{II}), \mathrm{Cr}(\mathrm{III}), \mathrm{Fe}(\mathrm{III})$ & Wastewater-graphic industry & Zanin et al. (2017) \\
Synthesized zeolite & $\mathrm{Pb}^{2+}, \mathrm{Cd}^{2+}, \mathrm{Cu}^{2+}, \mathrm{Ni}^{2+}, \mathrm{Mn}^{2+}$ & Industrial wastewater & He et al. (2016) \\
Cinoptilolite and chabazite & $\mathrm{Pb}, \mathrm{Cd}, \mathrm{Cu}, \mathrm{Zn}, \mathrm{Cr}, \mathrm{Ni}$ and $\mathrm{Co}$ & $\begin{array}{l}\text { Effluents contaminated with mixed } \\
\text { heavy metals }\end{array}$ & Ouki and Kavannagh (1997) \\
Natural zeolite & $\mathrm{Fe}, \mathrm{Pb}, \mathrm{Cd}$ and $\mathrm{Zn}$ & Synthetic mine water & Wingenfelder et al. (2015) \\
Clinoptilolite & $\mathrm{Pb}(\mathrm{II}), \mathrm{Cd}(\mathrm{II}), \mathrm{Cu}(\mathrm{II}), \mathrm{Co}(\mathrm{II})$, & Wastewater & Zamzow et al. (1990) \\
& $\mathrm{Cr}(\mathrm{III}), \mathrm{Zn}(\mathrm{II}), \mathrm{Ni}(\mathrm{II}), \mathrm{Hg}(\mathrm{II})$ & & Taamneh et al. (2016) \\
Jordanian zeolite & $\mathrm{Cd}$ and $\mathrm{Cu}$ ions & Aqueous solution & Yurekli (2016) \\
Zeolite/PSF & $\mathrm{Pb}$ and $\mathrm{Ni}$ ions & Synthetically prepared solutions & Tijani et al. (2013)
\end{tabular}


of a $100 \mathrm{ppb} \mathrm{Cr}(\mathrm{VI})$ solution was shown by unfunctionalized MWCNTs. Both functionalized and non-functionalized MWCNTs showed a superior adsorption capability to that of activated carbon. The major mechanisms for $\mathrm{Cr}(\mathrm{VI})$ removal have been identified as an ion exchange mechanism, intraparticle diffusion and electrostatic interactions. Kandah and Meunier (2007) also reported that the adsorption capacity for nickel ions from aqueous solutions increased significantly onto the surface of the oxidized CNTs compared to that on the as-produced CNTs.

Ruthiraan et al. (2015) made a comparative study between functionalized multiwall carbon nanotube (FMWCNTs), and magnetic biochar to determine the most efficient adsorbent to be employed in the $\mathrm{Cd}^{2+}$ ion removal from waste water. The statistical analysis proved that FMWCNTs had better adsorption capacity compared to magnetic biochar.

$\mathrm{Li}$ et al. (2010) reported that copper removal efficiency of CNTs/CAl (carbon nanotube/calcium alginate composites) was high and reaches $69.9 \%$ even at a lower $\mathrm{pH}$ of 2.1. The copper adsorption capacity of CNTs/CA can attain $67.9 \mathrm{mg} / \mathrm{g}$ at copper equilibrium concentration of $5 \mathrm{mg} / \mathrm{L}$. Tofighy and Mohammad (2011) used carbon nanotube (CNT) sheets for the removal of divalent heavy metals $\left(\mathrm{Cu}^{2+}, \mathrm{Zn}^{2+}, \mathrm{Pb}^{2+}, \mathrm{Cd}^{2+}, \mathrm{Co}^{2+}\right)$ from their solution in water. Preference of adsorption onto the oxidized CNT sheets was in the following order:

$\mathrm{Pb}^{2+}>\mathrm{Cd}^{2+}>\mathrm{Co}^{2+}>\mathrm{Zn}^{2+}>\mathrm{Cu}^{2+}$,

Saleh and Gupta (2012) used $\mathrm{MnO}_{2} / \mathrm{CNT}$ nanocomposite fixed bed for removal of $\mathrm{Pb}^{2+}$ from water. Atieh (2011) reported that the activated carbon (AC) coated with carbon nanotubes could be an excellent adsorbent to $\mathrm{Cr}(\mathrm{VI})$ ions with an adsorption capacity of $9.0 \mathrm{mg} / \mathrm{g}$.

Pyrzyńska and Bystrzejewski (2010) reported that carbon nanotubes and carbon-encapsulated magnetic nanoparticles have significantly higher sorption efficiency towards both studied metal ions $\left(\mathrm{Co}^{2+}\right.$ and $\left.\mathrm{Cu}^{2+}\right)$ in comparison with activated carbons. Onundi et al. (2011) synthesized a novel CNT-GAC (granular activated carbon) composite material and used for the removal of $\mathrm{Cu}^{2+}, \mathrm{Ni}^{2+}$ and $\mathrm{Pb}^{2+}$ ions from water via adsorption process. Experimental results on adsorption conditions indicated that copper, nickel and lead ions have highest adsorption capacity at $\mathrm{pH} 5$, while the maximum adsorbent dosage was $1 \mathrm{~g} / \mathrm{L}$ for copper and lead ions recording a sorption capacity of 1.013 and $0.853 \mathrm{mg} / \mathrm{g}$, respectively, and $2 \mathrm{~g} / \mathrm{L}$ for nickel recording $0.07 \mathrm{mg} / \mathrm{g}$. This novel material opens new door for various usage of the nanomaterials in different fields of application in the chemical, petrochemical industries and wastewater treatment plants, though more work is needed for the mass production of the material at reduced cost. Jaafar (2012) used modified CNTs $\left(\mathrm{HNO}_{3}\right.$ treated) for the removal of $\mathrm{Cu}^{2+}$ from water.
Yaghmaeian et al. (2015) reported that MWCNTs can effectively remove inorganic mercury from aqueous solutions as adsorbent and claimed that carbon nanotubes have high efficiency in adsorbing mercury. Mubarak et al. (2016) made a comparative study of the removal of $\mathrm{Pb}^{2+}$ ions and $\mathrm{Cr}^{3+}$ ions to determine the efficiency of carbon nanotubes (CNTs) produced using microwave heating as an adsorbent in removing heavy metal ions from waste water. The maximum adsorption capacities of both $\mathrm{Pb}^{2+}$ ions and $\mathrm{Cr}^{3+}$ ions onto the CNT were $15.34 \mathrm{mg} / \mathrm{g}$ for $\mathrm{Pb}^{2+}$ ions and $24.45 \mathrm{mg} / \mathrm{g}$ for $\mathrm{Cr}^{3+}$ ions.

Anitha et al. (2015) investigated the adsorption behaviors of heavy metal ions $\mathrm{Cd}^{2+}, \mathrm{Cu}^{2+}, \mathrm{Pb}^{2+}$, and $\mathrm{Hg}^{2+}$, in aqueous media using functionalized single-walled carbon nanotube (SWCNT) with functional groups - $\mathrm{COO}-,-\mathrm{OH}$, and $-\mathrm{CONH}_{2}$ using molecular dynamics (MD) simulations. They concluded that adsorption capacity was improved significantly using surface modification of SWCNT with carboxyl, hydroxyl, and amide functional group. In general, the following order of adsorption of the metal ions on functionalized CNT was observed:

$\mathrm{Pb}^{2+}>\mathrm{Cu}^{2+}>\mathrm{Cd}^{2+}>\mathrm{Hg}^{2+}$,

Kosa et al. (2012) investigated the removal of $\mathrm{Cu}^{2+}, \mathrm{Pb}^{2+}$, $\mathrm{Cd}^{2+}$ and $\mathrm{Zn}^{2+}$ from aqueous solutions using multi-walled carbon nanotubes modified with 8-hydroxyquinoline as adsorbent. The results showed that the removal of heavy metals was in the order of $\mathrm{Cu}^{2+}>\mathrm{Pb}^{2+} \approx \mathrm{Zn}^{2+}>\mathrm{Cd}^{2+}$ for $\%$ adsorption.

Doong and Chiang (2008) used titanate/carbon nanotube composites as a adsorbent for the removal of $\mathrm{Cu}^{2+}$ and $\mathrm{Pb}^{2+}$ ions from their solution in water. Results obtained in this study showed that nanomaterials are a promising adsorbent for removal heavy metal ions in solution. Abdulgafour et al. (2015) used $\mathrm{HNO}_{3}$ treated CNTs as adsorbent for the removal of $\mathrm{Co}, \mathrm{Pb}$, and $\mathrm{Cu}$ from wastewater of Al-Dora refinery. The adsorption capacity for $\mathrm{Pb}$ and $\mathrm{Cu}$ were 2.8 and $1.7 \mathrm{mg} / \mathrm{g}$, respectively. It was suggested that MWCNTs have great potential applications in environmental protection.

Lasheen et al. (2015) investigated the adsorption behavior of heavy metal ions $\left(\mathrm{Cu}^{2+}, \mathrm{Pb}^{2+}, \mathrm{Cd}^{2+}, \mathrm{Ni}^{2+}\right.$, and $\left.\mathrm{Cr}^{6+}\right)$ on as produced and oxidized MWCNTs and reported that the adsorption capacity of metals onto oxidized MWCNTs was greater than that on as-produced MWCNTs. The affinity order of the studied metals was found to be $\mathrm{Pb}^{2+}>\mathrm{Cu}^{2+}>\mathrm{Cr}^{6+}>\mathrm{Cd}^{2+}>\mathrm{Ni}^{2+}$. Gupta et al. (2011) studied the uncoated-MWCNTs, and alumina-coated MWC$\mathrm{NTs}$ for the removal of $\mathrm{Pb}$ ions from aqueous solutions in two modes, batch and fixed bed, and reported that the coated nanotubes exhibit better removal ability over uncoated.

Aliasghar et al. (2014) studied simple multiwalled carbon nanotubes (MWCNT) and functionalized MWCNT with the carboxyl agent (MWCNT-COOH) prepared by chemical 
vapor deposition (CVD) method for the separation of $\mathrm{Cd}$ and $\mathrm{Pb}$ by adsorption from water. It was revealed that there was a direct relationship between solution's temperature and cadmium and lead ions absorption rate on carbon nanotubes. Table 9 shows the summary of the CNTs for the use of wastewater treatment.

\section{Low-cost adsorbent materials}

Bobade and Eshtiag (2015) wrote a review entitled 'Heavy metals removal from wastewater by adsorption process' which was focused on the heavy metals removal based on the performance of various adsorbents such as natural materials, industrial byproduct, agricultural and biological waste, biopolymers and hydrogels.

Toxic heavy metals like $\mathrm{Pb}, \mathrm{Cd}, \mathrm{Zn}, \mathrm{Cu}, \mathrm{Ni}, \mathrm{Hg}, \mathrm{Cr}$, etc. from wastewater can be removed by adsorption process using agricultural wastes like rice husk, neem bark, black gram, waste tea; Turkish coffee, walnut shell, etc. Beside that low-cost industrial byproducts like fly ash, blast furnace sludge, waste slurry, lignin, iron(III) hydroxide and red mud, coffee husks, Areca waste, tea factory waste, sugar beet pulp, battery industry waste, sea nodule residue and grape stalk wastes have been explored for their technical feasibility to remove toxic heavy metals from contaminated water (Tripathi and Ranjan 2015). Malik et al. (2016) wrote a review entitled 'Removal of heavy metals from emerging cellulosic low-cost adsorbents' and discussed the most common and recent materials as cellulosic low-cost adsorbents. Crini et al. (2017) discussed polymer assisted ultrafiltration (PAUF) process for wastewater treatment including the advantages gained from the use of chitosan in the process of complexation-ultrafiltration.

Hegazi (2013) reported that low-cost adsorbents can be fruitfully used for the removal of heavy metals with a concentration range of $20-60 \mathrm{mg} / \mathrm{L}$ ( $\mathrm{pH}$ range 6-7). Agricultural and industrial waste byproducts such as rice husk and fly ash can be used for the elimination of heavy metals from wastewater. Kurniawan et al. (2006) reviewed over 100 papers (1984-2005) on the application of various lowcost adsorbents derived from agricultural waste, industrial byproduct or natural material for the removal of heavy metals [Cd(II), Cr(III), Cr(VI), Cu(II), Ni(II) and Zn(II)] from metal-contaminated wastewater.

Kadirvelu et al. (2001) prepared activated carbon from coir pith and studied the desorption of toxic heavy metals [Hg(II), $\mathrm{Pb}(\mathrm{II}), \mathrm{Cd}(\mathrm{II}), \mathrm{Ni}(\mathrm{II})$, and $\mathrm{Cu}(\mathrm{II})]$ from industrial wastewaters. The removal of heavy metals from undiluted industrial wastewaters depended upon the composition, and $\mathrm{pH}$.

Table 9 Summary of the use of zeolites for water treatment by adsorption

\begin{tabular}{|c|c|c|c|}
\hline Mater & Removal of & From & References \\
\hline MWCNTs & $\mathrm{Pb}(\mathrm{II})$ & Aqueous solution & Wang et al. (2007) \\
\hline Oxidized CNT & Ni ions & Aqueous solution & Kandah and Meunier (2007) \\
\hline CNT sheets & $\mathrm{Cu}^{2+}, \mathrm{Zn}^{2+}, \mathrm{Pb}^{2+}, \mathrm{Cd}^{2+}, \mathrm{Co}^{2+}$ & Water solution & Tofighy and Mohammad (2011) \\
\hline Modified CNTs & $\mathrm{Cu}^{2+}$ & Water & Jaafar (2012) \\
\hline CNTs and Carbon encapsulated magnetic NPTs & $\mathrm{Co}(\mathrm{II}), \mathrm{Cu}(\mathrm{II})$ & Aqueous solution & Pyrzynska and Bystrzejewski (2010) \\
\hline MWCNTs & $\mathrm{Cr}(\mathrm{VI})$ & Aqueous solution & Pillay et al. (2009) \\
\hline $\mathrm{MnO}_{2} / \mathrm{CNT}$ & $\mathrm{Pb}(\mathrm{II})$ & Aqueous solution & Saleh and Gupta (2012) \\
\hline FMWCNTs & $\mathrm{Cd}(\mathrm{II})$ & Wastewater & Ruthiraan et al. (2015) \\
\hline AC/CNTs & $\mathrm{Cr}(\mathrm{VI})$ & Polluted water & Atieh (2011) \\
\hline CNTs/Cal & $\mathrm{Cu}(\mathrm{II})$ & Aqueous solution & Li et al. (2010) \\
\hline CNT-GAC & $\mathrm{Cu}(\mathrm{II}), \mathrm{Ni}(\mathrm{II})$ and $\mathrm{Pb}(\mathrm{II})$ & Water & Onundi et al. (2011) \\
\hline MWCNTs & $\mathrm{Hg}(\mathrm{II})$ & Aqueous solution & Yaghmaeian et al. (2015) \\
\hline CNTs/microwave heating & $\mathrm{Pb}(\mathrm{II}), \mathrm{Cr}(\mathrm{III})$ & Wastewater & Mubarak et al. (2016) \\
\hline SWCNT & $\mathrm{Pb}^{2+}, \mathrm{Cu}^{2+}, \mathrm{Cd}^{2+}, \mathrm{Hg}^{2+}$ & Aqueous solutions & Anitha et al. (2015) \\
\hline Titanate/carbon nanotube composite & $\mathrm{Cu}(\mathrm{II}), \mathrm{Pb}(\mathrm{II})$ & Solution in water & Anitha et al. (2015) \\
\hline Modified with 8-hydroxyquinoline & $\mathrm{Cu}(\mathrm{II}), \mathrm{Pb}(\mathrm{II}), \mathrm{Cd}(\mathrm{II})$ and $\mathrm{Zn}(\mathrm{II})$ & Aqueous solutions & Kosa et al. (2012) \\
\hline HNO3 treated CNTs & $\mathrm{Co}, \mathrm{Pb}$, and $\mathrm{Cu}$ from & $\begin{array}{l}\text { Wastewater of Al- } \\
\text { Dora refinery }\end{array}$ & Abdulgafour et al. (2015) \\
\hline Oxidized and un oxidized MWCNTs & $\mathrm{Cu}^{2+}, \mathrm{Pb}^{2+}, \mathrm{Cd}^{2+}, \mathrm{Ni}^{2+}, \mathrm{Cr}^{6+}$ & Aqueous solution & Lasheen et al. (2015) \\
\hline Uncoated and $\mathrm{Al}_{2} \mathrm{O}_{3}$ coated MWCNTs & $\mathrm{Pb}^{2+}$ & Aqueous solutions & Gupta et al. (2011) \\
\hline $\begin{array}{l}\text { MWCNT and MWCNT with the carboxyl agent } \\
\text { (MWCNT-COOH) }\end{array}$ & $\mathrm{Pb}(\mathrm{II}), \mathrm{Cd}(\mathrm{II})$ & Aqueous solutions & Aliasghar et al. (2014) \\
\hline
\end{tabular}


Al-Jlil (2010) studied to remove heavy metals such as $\mathrm{Cu}, \mathrm{Co}, \mathrm{Zn}, \mathrm{Pb}, \mathrm{As}, \mathrm{Cd}$ and $\mathrm{Cr}$ from industrial wastewater by adsorption using local bentonite clay and roasted date pits and reported that the minimum removal efficiency of the adsorption of metal ions on bentonite clay and roasted date pits was $97 \%$. The authors suggested for removing the minimum removal efficiency of the adsorption of metal ions on bentonite clay and roasted date pits was $97 \%$.

Meena et al. (2005) reported the removal of Cd(II), $\mathrm{Pb}(\mathrm{II}), \mathrm{Hg}(\mathrm{II}), \mathrm{Cu}$ (II), Ni(II), $\mathrm{Mn}$ (II) and $\mathrm{Zn}$ (II) by carbon aerogel from aqueous solutions. Agbozu and Emoruwa studied (Agbozu and Emoruwa 2014) the removal efficiency of metals $(\mathrm{Cr}, \mathrm{Cu}, \mathrm{Pb}, \mathrm{Fe}, \mathrm{Cd})$ from the solution of mixed metal ions using coconut husk as adsorbent. The percentage removal of metal increased with increasing weight of coconut husk and the observed trend of percentage removal of metal ions was:

$\mathrm{Cr}>\mathrm{Cu}>\mathrm{Pb}>\mathrm{Fe}>\mathrm{Cd}$.

Ibigbami et al. (2016) used the combination of hydrogen peroxide and activated bentonite clay as adsorbent for removal of $\mathrm{Fe}^{2+}, \mathrm{Zn}^{2+}$ and $\mathrm{Ni}^{2+}$ from pharmaceutical effluent. Ramalingam et al. (2013) studied the removal of $\mathrm{Pb}$ (II) and $\mathrm{Cd}(\mathrm{II})$ from wastewater using Calotropis Procera roots as an adsorbent. This adsorbent can be a good choice for adsorption of not only $\mathrm{Pb}$ (II) and $\mathrm{Cd}$ (II) ions but also other heavy metal ions in waste water stream. Bandela et al. (2016) used agricultural waste for the removal of $\mathrm{Cu}^{2+}$ from water. Rana et al. (2014) used sulphuric acid treated sugarcane as an adsorbent for the removal of $\mathrm{Cu}^{2+}$ from synthetic waster. Dwivedi and Rajput (2014) reported that the maximum removal of copper and cadmium ion from aqueous solution using tea waste as adsorbent, is 89 and $87 \%$, respectively, at the optimum condition. Adie and Okuofu (2012) investigated the adsorption of heavy metal ions $\left(\mathrm{Pb}^{2+}\right.$ and $\mathrm{Cd}^{2+}$ ) using activated carbon from Borassusaethiopum (seed shells) and Cocos nucifera (shells). The obtained experimental results showed that process parameters such as adsorbent dose, initial metal concentration, and contact time affected uptake metal ions by both adsorbents.

Phadtare and Patil (2015) used sweet lime and lemon skin as adsorbents to remove $\mathrm{Cr}(\mathrm{VI})$ from wastewater. The maximum adsorption takes place in the $\mathrm{pH}$ range 4-6, and the increase in $\mathrm{pH}$ shows negative impact on adsorption of $\mathrm{Cr}(\mathrm{VI})$. Adil et al. (2014) reported that the paper mulberry bio-char (PMB) was more effective and exhibited a higher adsorption potential for cadmium, copper, chromium, lead and zinc than commercially available silica powder.

Okoya et al. (2014) reported that cocoa husk, an agricultural waste material, have potential as an adsorbent to remove toxic heavy metal like chromium and lead from industrial waste water. Moodley et al. (2011) investigated the adsorption capacity of a low-cost adsorbent (pine sawdust) by treating wastewater containing nickel(II) and other heavy metal ions. The authors claimed that the use of pine sawdust could be a promising solution to the elimination of nickel ions from multi-component aqueous solutions. The use of cow dung as a promising adsorbent in the removal of heavy metals ( $\mathrm{Zn}, \mathrm{Cu}, \mathrm{Pb}, \mathrm{Ni}, \mathrm{Cd}$, etc.) from waste waters and environment is well established (Ojedokun and Bello 2016). Wan et al. (2010) used chitosan-coated sand for removal of copper(II) and lead(II) ions in water.

Adsorbents of heavy metal ions can range cheap biowaste recycling to functional nanomaterials (Wang et al. 2016). Nanomaterials from bio-waste adsorbents, contains functional groups, such as amine, carboxyl, and thiol groups, which can form co-ordinate bonds with heavy metal ions by donation of lone-pair electrons. These materials allow easy switching between the trapping and release of heavy metal ions by adjusting the $\mathrm{pH}$ from neutral to acid conditions. Table 10 shows summary of some low-cost materials which were used for the separation of heavy metals from wastewater.

\section{Graphene oxide-water treatment}

Graphene is another type of carbon material as nanosorbent. Numerous reports described the utilization of graphene and its composites as good adsorbents for the removal of dyes and heavy metal ions from aqueous solutions (Zhao et al. 2011; Cong et al. 2012; Huang et al. 2011; Vilela et al. 2016). The applications of graphene in environment are mainly the removal of pollutants in water. There are two ways to use graphene materials in water purification: photo-catalysis and adsorption. In adsorption surface area and useful chemical groups in carbon material give different options to produce efficient adsorbents depending on different synthesis conditions.

Graphene-oxide membranes have attracted considerable attention as promising candidates. Sun et al. (2013) discussed the purification properties of Go membranes prepared via a simple drop-casting method. It was reported that sodium salts permeated quickly through the GO membranes, but on the other hand heavy metal salts infiltrated much more slowly. Copper sulfate and organic contaminants, such as rhodamine B, are blocked entirely because of their strong interactions with the GO membranes. It was suggested by Sun et al. that GO membranes are a promising candidate in future applications, such as barrier separation and wastewater purification filtration technologies.

The Manchester-based group developed graphene membranes which are strategy to avoid the swelling of the membrane when exposed to water. The pore size in the membrane can be precisely controlled so that the membrane can sieve common salts out of salty water and make it safe to drink.

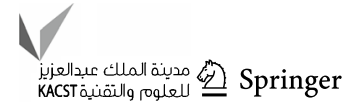


Table 10 Summary of low cost materials for the separation of heavy metals from water/wastewater

\begin{tabular}{|c|c|c|c|}
\hline Material & Removal of & From & References \\
\hline $\begin{array}{l}\text { AC from coir pith (agricultural } \\
\text { waste) }\end{array}$ & $\begin{array}{l}\mathrm{Hg}(\mathrm{II}), \mathrm{Pb}(\mathrm{II}), \mathrm{Cd}(\mathrm{II}), \mathrm{Ni}(\mathrm{II}) \text {, and } \\
\quad \mathrm{Cu}(\mathrm{II})\end{array}$ & Industrial wastewaters & Kadirvelu et al. (2001) \\
\hline Rice husk & $\mathrm{Fe}, \mathrm{Pb}$ and $\mathrm{Ni}$ & Wastewater & Hegazi(2013) \\
\hline Fly ash & $\mathrm{Cd}$ and $\mathrm{Cu}$ & Wastewate & Hegazi (2013) \\
\hline Bentonite clay and roasted date pits & $\mathrm{Cu}, \mathrm{Co}, \mathrm{Zn}, \mathrm{Pb}, \mathrm{As}, \mathrm{Cd}$ & Industrial wastewater & Al-Jlil (2010) \\
\hline Carbon aerogel & $\begin{array}{l}\mathrm{Cd}(\mathrm{II}), \mathrm{Pb}(\mathrm{II}), \mathrm{Hg}(\mathrm{II}), \mathrm{Cu}(\mathrm{II}), \mathrm{Ni}(\mathrm{II}) \\
\mathrm{Mn}(\mathrm{II}) \text { and } \mathrm{Zn}(\mathrm{II})\end{array}$ & Aqueous solution & Meena et al. (2005) \\
\hline Coconut husk & $\mathrm{Cu}, \mathrm{Fe}, \mathrm{Pb}, \mathrm{Cr}, \mathrm{Cd}$ & Synthetically prepared wastewater & Agbozu and Emoruwa (2014) \\
\hline $\begin{array}{l}\text { Combination of } \mathrm{H}_{2} \mathrm{O}_{2} \text { and activated } \\
\text { bentonite clay }\end{array}$ & $\mathrm{Fe}^{2+}, \mathrm{Zn}^{2+}$ and $\mathrm{Ni}^{2+}$ & Industrial wastewater & Ibigbami et al. (2016) \\
\hline Calotropis Procera roots & $\mathrm{Pb}(\mathrm{II}), \mathrm{Cd}(\mathrm{II})$ & Wastewater & Ramalingam et al. (2013) \\
\hline Agro waste & $\mathrm{Cu}^{2+}$ & Water & Bandela et al. (2016) \\
\hline $\mathrm{H}_{2} \mathrm{SO}_{4}$ treated sugar cane & $\mathrm{Cu}^{2+}$ & Synthetically prepared wastewater & Rana et al. (2014) \\
\hline Tea waste & $\mathrm{Cu}^{2+}, \mathrm{Cd}^{2+}$ & Aqueous solution & Dwivedi and Rajput (2014) \\
\hline Activated carbon from shell & $\mathrm{Pb}(\mathrm{II})$ and $\mathrm{Cd}(\mathrm{II})$ & Aqueous solution & Adie and Okuofu (2012) \\
\hline Lime and lemon skin & $\mathrm{Cr}(\mathrm{VI})$ & Synthetic solution of $\mathrm{K}_{2} \mathrm{Cr}_{2} \mathrm{O}_{7}$ & Phadtare and Patil (2015) \\
\hline PMB & $\begin{array}{l}\text { Cadmium, copper, chromium, lead } \\
\text { and zinc }\end{array}$ & Industrial waste water & Adil et al. (2014) \\
\hline chitosan-coated sand & $\mathrm{Cu}(\mathrm{II}), \mathrm{Pb}(\mathrm{II})$ ions & Aqueous solution & Wan et al. (2010) \\
\hline Cocoa husk & Chromium and lead & Industrial waste water & Okoya et al. (2014) \\
\hline Pine sawdust & $\mathrm{Ni}(\mathrm{II})$ & Waste water & Moodley et al. (2011) \\
\hline Cowdung & $\mathrm{Zn}, \mathrm{Cu}, \mathrm{Pb}, \mathrm{Ni}, \mathrm{Cd}$ & Wastewater & Ojedokun and Bello (2016) \\
\hline
\end{tabular}

By 2025 the UN expects that $14 \%$ of the world's population will encounter water scarcity. This technology has the potential to revolutionize water filtration across the world, in particular in countries which cannot afford large scale desalination plants (Robinson 2017; Abraham et al. 2017). Graphine oxide (GO) as adsorbent for the removal of heavy metals is getting more attention due to its high surface area, mechanical strength, light weight, flexibility and chemical stability (Gopalakrishnan et al. 2015; Taherian et al. 2013; Kyzas et al. 2014) wrote a review and discussed the application of GO (particularly as magnetic particles) as an adsorbent for wastewater treatment such as heavy metals separation (mercury, cadmium, copper, chromium, arsenic) and also organics (antibiotics, dyes, i.e. Reactive black 5, etc.).

Lee et al. (2013) fabricated reduced graphene oxide (rGO) nanoplatelets composite membrane (UF) for MBRs for wastewater treatment. It was reported that the GO membrane had anti-biofouling capability due to its hydrophilicity and electrostatic repulsion characteristics including superior mechanical strength and water permeability.

Mishra and Ramaprabhu (2011) used functionalized graphene sheets for arsenic removal and desalination of sea water and reported that maximum adsorption capacities, using Langmuir isotherm, for arsenate, arsenite and sodium were found to be nearly 142, 139 and $122 \mathrm{mg} / \mathrm{g}$, respectively.

Gollavelli et al. (2013) synthesized smart magnetic graphene (SMG) by microwave irradiation of graphene oxide (GO) and ferrocene precursors. The SMG possesses increased adsorption sites with tunable superparamagnetic properties (50 emu/g, 1:7 wt\%), facilitating the adsorption and magnetic separation of aqueous $\mathrm{Cr}(\mathrm{VI})$, As(V), and $\mathrm{Pb}$ (II) with $\sim 99 \%$ removal efficiencies down to the $1 \mathrm{ppb}$ level. Han et al. (2013) fabricated ultrathin $(\approx 22-53 \mathrm{~nm}$ thick) graphene nanofiltration membranes (uGNMs) on microporous substrates. High retention (>99\%) for organic dyes and moderate retention $(\approx 20-60 \%)$ for ion salts were resulted from uGNMs.

Zare-Dorabei et al. (2016) used graphene oxide which was chemically modified with 2,2'-dipyridylamine (GODPA) for the adsorption of four toxic heavy metals, $\mathrm{Pb}(\mathrm{II})$, $\mathrm{Cd}(\mathrm{II}), \mathrm{Ni}(\mathrm{II})$ and $\mathrm{Cu}(\mathrm{II})$, from aqueous solutions. The adsorption kinetic studies and equilibrium isotherms for evaluating the mechanism of adsorption process showed a good fit to the pseudo-second order and Langmuir model, respectively. The maximum adsorption capacities $\left(Q_{\mathrm{m}}\right)$ of this adsorbent were 369.749, 257.201, 180.893 and $358.824 \mathrm{mg} / \mathrm{g}$ for lead, cadmium, nickel and copper ions, respectively. The removal performance of adsorbent on the real wastewater samples also showed the feasibility of adsorbent for applying in industrial purposes.

Vasudevan and Lakshmi (2012) prepared graphene by a facile liquid phase exfoliation and reported that graphene is an excellent phosphate adsorbent with an adsorption capacity of up to $89.37 \mathrm{mg} / \mathrm{g}$ at an initial phosphate concentration 
of $100 \mathrm{mg} / \mathrm{L}$ and temperature of $303 \mathrm{~K}$. Thermodynamic studies revealed that the adsorption reaction was a spontaneous and endothermic process.

Chandra et al. (2010) reported the removal of As(III) and $\mathrm{As}(\mathrm{V})$ from water using magnetite-reduced graphene oxide (M-RGO) composites via a chemical reaction with magnetite particle size average of $\sim 10 \mathrm{~nm}$. The composites showed near complete (over $99.9 \%$ ) arsenic removal within $1 \mathrm{ppb}$ and suggested that these composites show high binding capacity for.

Meidanchi and Akhavan (2014) introduced superparamagnetic $\mathrm{ZnFe}_{2} \mathrm{O}_{4} /$ reduced graphene oxide (rGO) composites containing $\mathrm{ZnFe}_{2} \mathrm{O}_{4}$ nanoparticles (with $\sim 5-20 \mathrm{~nm}$ sizes) attached onto $\mathrm{rGO}$ sheets for the separation of dyes from their solution. Chen et al. (2016) proposed a novel and easy method to prepare cellulose/GO hydrogel with good adsorption of heavy metal ions $\left(\mathrm{Cu}^{2+}, \mathrm{Zn}^{2+}, \mathrm{Fe}^{3+}, \mathrm{Pb}^{2+}\right)$ from aqueous solutions.

Mukherjee et al. (2016) studied the purification of heavy metal solution with UF grade GOMMM and reported the absorption capacity of different heavy metals $\left(\mathrm{Pb}^{2+}, \mathrm{Cu}^{2+}\right.$, $\mathrm{Cd}^{2+}$ and $\left.\mathrm{Cr}^{6+}\right)$. Table 11 shows absorption capacity of different heavy metals on GO MMM.

Madadrang et al. (2012) linked the chelating groups to graphine oxide surfaces via a silanization reaction between $N$-(trimethoxysilylpropyl) ethylenediamine triacetic acid (EDTA-silane) and hydroxyl groups on GO surface. The adsorption capacity for $\mathrm{Pb}(\mathrm{II})$ removal was found to be $479 \pm 46 \mathrm{mg} / \mathrm{g}$ at $\mathrm{pH} 6.8$.

Varma et al. (2013) synthesized GNS/ $-\mathrm{MnO}_{2}$ composite and used as adsorbent for the removal of $\mathrm{Ni}$ (II) ions from aqueous solution. It was observed that the adsorption capacity of GNS/ $\delta-\mathrm{MnO}_{2}$ for $\mathrm{Ni}(\mathrm{II})$ was 1.5 times higher than that for $\mathrm{MnO}_{2}$, which mainly comes from $\mathrm{MnO}_{2}$ nanoparticles growth on the surfaces of GNS. Zhu et al. (2016) synthesized GO-MCNTs-DETA nanocomposites by mixing MCNTs in GO colloids and further functionalized with diethylenetriamine (DETA), and studied solid-phase extraction and analysis of $\mathrm{Cr}$ (III), $\mathrm{Fe}(\mathrm{III}), \mathrm{Pb}(\mathrm{II})$, and $\mathrm{Mn}$ (II) ions at the trace levels in wastewater. Cui et al. (2015) reported that resin loaded magnetic b-cyclodextrin bead and graphene oxide sheet (MCD-GO-R) were synthesized successfully and found to be an excellent adsorbent for $\mathrm{Hg}$ (II) removal.

Table 11 Absorption capacity of different heavy metals on GO MMM
The maximum adsorption capacity was $88.43 \mathrm{mg} / \mathrm{g}$ at $323 \mathrm{~K}$ and $\mathrm{pH} 7.1$.

Wang et al. (2017) prepared a graphene foam/ $/ \mathrm{TiO}_{2}$ nanosheet hybrid, which is able to effectively remove both chromium(VI) cations and organic pollutants. Firdhouse and Lalitha (2016) revealed that the graphene loaded with the silver nanoparticles and oleifera seed powder possessed excellent adsorbent properties and showed good efficacy on reusability compared to conventional activated charcoal simultaneously.

Trihalomethanes (THMs) separation from water was studied via functionalized nanoporous graphene (FNG) under induced pressure by Azamat et al. (2015). The results showed that a functionalized nanoporous graphene with a small diameter was impermeable to THMs. In contrast, a functionalized nanoporous graphene with a large diameter was shown to be permeable to THMs. Table 12 shows the summary of graphene related membrane/material used for wastewater treatment.

\section{Removal of radioactive material}

The term radioactive is defined as an unstable particle that releases subatomic particles. Radioactive waste is waste that contains radioactive material. Radioactive waste is usually a byproduct of nuclear power generation and other applications of nuclear fission or nuclear technology, such as research and medicine. Radioactive waste is hazardous to most forms of life and the environment, and is regulated by government agencies to protect human health and the environment. "Information about radionuclides removal by membrane technology [high pressure RO-nanofiltration (NF) membranes] is very limited. It is usually mentioned in the literature that $\mathrm{RO} / \mathrm{NF}$ membranes remove at least $95 \%$ of radionuclides, in addition to improving other water quality parameters that may be a concern (Munter 2013). Rana et al. (2013) wrote a review entitled 'Radioactive decontamination of water by membrane processes' and discussed the advancement in the technologies of nuclear waste treatment including membrane separation technologies for treatment of radioactive wastes.

Ramanjaneyulu et al. (2010) fabricated polyvinylchloride (PVC) based liquid membrane ion selective electrode (ISE) for Cs removal. Dulama et al. (2009) combined UF and RO processes for the treatment of low-level radioactive water containing $\mathrm{Pu}$. It was reported that the decontamination efficiency achieves $99.94 \%$ and the volume concentration ratio achieves 12.5 at $\mathrm{pH} 10$ for solution fed into the membrane separation system. Rosell (2015) used membrane technology to treat the radioactive waste water using ceramic membranes. A total volume of $2,4 \mathrm{~m}^{3}$ with an average gamma activity of $4.4 \times 10^{5} \mathrm{~Bq} / \mathrm{L}$ has been

\begin{tabular}{lc}
\hline Metal/ions & $\begin{array}{l}\text { Capacity } \\
(\mathrm{mg} / \mathrm{g})\end{array}$ \\
\hline $\mathrm{Pb}^{2+}$ & 79 \\
$\mathrm{Cu}^{2+}$ & 75 \\
$\mathrm{Cd}^{2+}$ & 68 \\
$\mathrm{Cr}^{6+}$ & 154 \\
\hline
\end{tabular}

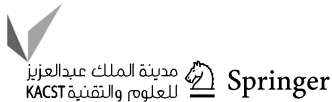


Table 12 Summary of graphene related membrane/material used for waste water treatment

\begin{tabular}{|c|c|c|c|}
\hline Membrane/material & Removal of & From & References \\
\hline UF grade GO MMM & $\mathrm{Pb}^{2+}, \mathrm{Cu}^{2+}, \mathrm{Cd}^{2+}, \mathrm{Cr}^{6+}$ & Heavy metal solution & Mukherjee et al. (2016) \\
\hline uGNMs & Organic dyes and ion salts & Aqueous solution & Han et al. (2013) \\
\hline Functionalized graphene sheets & $\begin{array}{l}\text { Arsenate, arsenite and desalination of } \\
\text { sea water }\end{array}$ & Aqueous solution and sea water & Mishra and Ramaprabhu (2011) \\
\hline $\begin{array}{l}\text { rGO nanoplatelets composite mem- } \\
\text { brane (UF) for MBRs }\end{array}$ & Wastewater treatment & Water & Lee et al. (2013) \\
\hline Go membrane & $\begin{array}{l}\text { Copper sulfate and organic contami- } \\
\text { nants, such as rhodamine B, }\end{array}$ & Aqueous solution & Sun et al. (2013) \\
\hline GO (particularly magnetic particles) & $\begin{array}{l}\text { Wastewater treatment (mercury, cad- } \\
\text { mium, copper, chromium, arsenic) } \\
\text { and also organics (antibiotics, dyes) }\end{array}$ & Wastewater & Kyzas et al. (2014) \\
\hline $\mathrm{GNS} / \delta-\mathrm{MnO}_{2}$ & $\mathrm{Ni}(\mathrm{II})$ & Aqueous solution & Varma et al. (2013) \\
\hline SMG & $\mathrm{Cr}(\mathrm{VI}), \mathrm{As}(\mathrm{V}), \mathrm{Pb}(\mathrm{II})$ & Aqueous solution & Gollavelli et al. (2013) \\
\hline GO-DPA & $\mathrm{Pb}(\mathrm{II}), \mathrm{Cd}(\mathrm{II}), \mathrm{Ni}(\mathrm{II}), \mathrm{Cu}(\mathrm{II})$ & Aqueous solution & Zare-Dorabei et al. (2016) \\
\hline M-RGO composite & $\mathrm{As}(\mathrm{III}), \mathrm{As}(\mathrm{V})$ & Water & Chandra et al. (2010) \\
\hline EDTA-graphene oxide & $\mathrm{Pb}(\mathrm{II})$ & Aqueous solution & Madadrang et al. (2012) \\
\hline Graphene & Phosphate & Aqueous solution & Vasudevan and Lakshmi (2012) \\
\hline Cellulose/GO hydrogel & $\mathrm{Cu}+{ }^{2}, \mathrm{Zn}^{2+}, \mathrm{Fe}^{3+}, \mathrm{Pb}^{2+}$ & Aqueous solution & Chen and wang (2016) \\
\hline $\mathrm{ZnFe}_{2} \mathrm{O}_{4} / \mathrm{rGo}$ composite & Dyes & Water solution & Meidanchi and Akhavan (2014) \\
\hline Graphene foam $/ \mathrm{TiO}_{2}$ nanosheet & $\begin{array}{l}\text { Chromium (VI) and organic pollutants } \\
\text { simultaneously. }\end{array}$ & Water solution & Wang et al. (2017) \\
\hline MCD-GO-R & $\mathrm{Hg}(\mathrm{II})$ & Aqueous solution & Cui et al. (2015) \\
\hline GO-MCNTs-DETA & $\mathrm{Cr}(\mathrm{III}), \mathrm{Fe}(\mathrm{III}), \mathrm{Pb}(\mathrm{II}), \mathrm{Mn}(\mathrm{II})$ & Wastewater & Zhu et al. (2016) \\
\hline FNG & THMs & Water & Azamat et al. (2015) \\
\hline
\end{tabular}

Table 13 Cellulose-based titanate support performance for ${ }^{88} \mathrm{Sr}$ and ${ }^{133} \mathrm{Cs}$ removal from deionized water media (double passes)

\begin{tabular}{lll}
\hline Membrane type & ${ }^{88} \mathrm{Sr}$ & ${ }^{133} \mathrm{Cs}$ \\
& $D_{f}^{8}$ & $D_{f}$ \\
\hline $\mathrm{CST}_{\text {-Yellow }}$ & No affinity & $17(5)$ \\
$\mathrm{CST}_{\text {-Gray }}$ & No affinity & $22(3)$ \\
$\mathrm{MST}_{\text {-Gray }}$ & $41(2)$ & No affinity \\
CST-MST $_{\text {-Gray }}$ & $25(4)$ & $30(3)$ \\
\hline
\end{tabular}

reduced to $140 \mathrm{~L}$ of concentrate with an average activity of $5.4 \times 10^{6} \mathrm{~Bq} / \mathrm{L}$. The produced permeate held an average activity of $1.9 \times 10^{3} \mathrm{~Bq} / \mathrm{L}$.

Oji et al. (2009) prepared prototype membrane of monosodium titanate (MST) and crystalline silicotitanate (CST) membranes with the three support materials [polytetrafluoroethylene (PTFE), polyethylene (PE) and cellulose (pulp and paper)]. These membranes were used for the removal of ${ }^{88} \mathrm{Sr}$ and ${ }^{133} \mathrm{Cs}$ from aqueous solution. The removal of both ${ }^{88} \mathrm{Sr}$ and ${ }^{133} \mathrm{Cs}$ from a solution of distilled and de-ionized water is summarized in Table 13.

Numbers in bracket represent standard deviations (two types of cellulose pulp materials, the yellow and gray pulp material with different $\mathrm{pH}$ values, from Augusta Print
Company were used. The yellow and gray pulp had water contents of 96 and $91 \%$, respectively, with $\mathrm{pH}$ values of 4.3 and 7.5). *Diffusion coeff.

It was reported that the titanium-impregnated ionexchange membranes supported on inert fibrils can be effective in the removal of radionuclides like strontium and cesium from caustic aqueous nuclear waste environments. monosodium titanate (MST) is known to have great affinity for other actinides like plutonium, neptunium and even uranium. It was also observed that CST supported on PTFE or PE fibrils had a significant affinity for both cesium and strontium. On the other hand, MST supported on PTFE or PE showed only affinity for strontium (Oji et al. 2009).

Weerasekara et al. (2013) investigated the potential use of a hybridized adsorption/microfiltration system for the selective removal of hazardous cobalt and strontium ions from nuclear power plant laundry wastewater via hybridized adsorption/microfiltration processes. A crystalline silicotitanate (CST) and four different iron oxides were fabricated and used as adsorbents, which had different crystal structures and adsorptive mechanisms, such as ion exchange and surface coordination. CST was most effective at removing $\mathrm{Co}$ and $\mathrm{Sr}$ from laundry wastewater $(>90 \%)$. The presence of other ions (e.g., $\mathrm{K}^{+}, \mathrm{Na}^{+}, \mathrm{Ca}^{2+}$, and $\mathrm{Mg}^{2+}$ ) had no significant impact on the affinities of the adsorbents for $\mathrm{Co}$ and $\mathrm{Sr}$ 
ions. The selectivity coefficients of CST for both $\mathrm{Co}$ and $\mathrm{Sr}$ ions ranged from 3 to 130. CST and ferrihydrite adsorbents were successfully regenerated using $\mathrm{NaCl}$ and $\mathrm{HCl}$ solutions, respectively. The addition of adsorbents to the microfiltration system enhanced the membrane permeability ( $>30 \%)$, probably because the cobalt species were removed prior to precipitation at the membrane surface. Substantial and stable metal removals (> 90\% for both Co and $\mathrm{Sr}$ ) were achieved during $50 \mathrm{~h}$ of continuous system operations.

Awual et al. (2016) successfully developed novel macrocyclic ligand of $o$-benzo- $p$-xylyl-22-crown-6-ether (OBPX22C6) and immobilized onto mesoporous silica for the preparation of hybrid adsorbent. The potential and feasibility of the hybrid adsorbent as being Cs selective was evaluated, in terms of sensitivity, selectivity and reusability. The results clarified that the Cs removal process was rapid and reached saturation within a short time.

Park et al. (2010) used spherical beads of ammonium molybdophosphate-polyacrylonitrile (AMP-PAN) as the adsorptive material for the removal of $\mathrm{Co}, \mathrm{Sr}$ and $\mathrm{Cs}$ in the radioactive laundry wastewater generated from nuclear power plants. The maximum adsorption capacities were $0.16,0.18$ and $0.61 \mathrm{mmol} / \mathrm{g}$ for $\mathrm{Co}^{2+}, \mathrm{Sr}^{2+}$ and $\mathrm{C}^{\mathrm{s}+}$, respectively.

Yamaguchi et al. (2014) studied the carbon- $\gamma-\mathrm{Fe}_{2} \mathrm{O}_{3}$ nanoparticle composite of mesoporous carbon, bearing $\mathrm{COOH}-$ and phenolic $\mathrm{OH}$ - functional groups on its surface as absorbent for radioactive material emitted by the Fukushima Daiichi nuclear power plant accident. It was reported that it had a remarkable and magnetically separable adsorbent power. It was reported that the adsorbent capacity of AMP-PAN was $0.16,0.18$ and $0.61 \mathrm{mmol} / \mathrm{g}$ for $\mathrm{Co}^{2+}, \mathrm{Sr}^{2+}$ and $\mathrm{Cs}^{+}$, respectively.

Jang et al. (2014) revealed the ability of Prussian bluecoated magnetic nanoparticles to eliminate cesium from radioactive contaminated waste. It was reported that the magnetic adsorbent with Prussian blue possesses high cesium adsorption capacity and can be easily recovered once spread into an open environment. Bo (2012) used $\mathrm{Ag}_{2} \mathrm{O}$ deposited titanate lamina $\left(\gamma-\mathrm{Al}_{2} \mathrm{O}_{3}\right.$ nanofibers $)$ as an adsorbent for the removal of radioactive iodine from water. Nishiyama et al. (2016) developed a removal system of ${ }^{90} \mathrm{Sr}$ from aqueous solution by HAP (hydroxyapatite) column procedure and reported that more than $90 \%$ of ${ }^{90} \mathrm{Sr}$ was adsorbed and removed from the ${ }^{90} \mathrm{Sr}$ containing solution.

Lee et al. (2015) studied the removal of Cs contained in the high-radioactive seawater waste (HSW), by adsorption with IE911 (crystalline silicotitanate type). It was observed that, Cs and Sr were adsorbed about 99 and less than 5\%, respectively, under experimental conditions. Ye et al. (2008) reported the adsorption of strontium and calcium ions by composite magnetic particles derived from $\mathrm{Fe}_{3} \mathrm{O}_{4}$ and bis(trimethoxysilylpropyl)amine (TSPA). The adsorption occurs rapidly in the first $30 \mathrm{~min}$. It was observed that the equilibrium adsorption amount of both strontium and calcium ions increases with the increase in initial ion concentration and initial solution $\mathrm{pH}$, but to decrease gradually with the increase in ionic strength. Fang et al. (2016) reported that zeolite 4A strong capability for purifying radioactive waste, such as $\mathrm{Sr}^{2+}, \mathrm{Cs}^{+}$, and $\mathrm{Co}^{2+}$ in water. It was suggested that zeolite $4 \mathrm{~A}$ has considerable potential in the treatment of radioactive wastewater. Zhang et al. (2010) reported that the adsorption of ${ }^{63} \mathrm{Ni}$ on NKF-6 zeolite was strongly dependent on $\mathrm{pH}$ and ionic strength, and the adsorption of ${ }^{63} \mathrm{Ni}$ increased with increasing NKF-6 zeolite content. The experimental results suggested that the adsorption process of ${ }^{63} \mathrm{Ni}$ on NKF-6 zeolite was spontaneous and endothermic. Fan et al. (2003) tested the adsorption capacity of ${ }^{18} \mathrm{~F}$ in hydroxyapatite, fluorspar, calcite, quartz and quartz activated by ferric ions. Their adsorption capacities were in follow the order:

$$
\begin{aligned}
& \text { Hydroxyapatite }>\text { Fluorspar }>\text { Quartz activated using ferric ions } \\
& \quad>\text { Calcite }>\text { Quartz. }
\end{aligned}
$$

Researchers at Rice University and Kazan Federal University in Russia reported that oxidatively modified carbon (OMC) material is inexpensive and highly efficient at absorbing radioactive metal cations, including cesium and strontium, toxic elements released into the environment when the Fukushima plant melted down after an earthquake and tsunami in March 2011. OMC can easily trap common radioactive elements found in water floods from oil extraction, such as uranium, thorium and radium (Williams 2017). Khannanov et al. (2017) reported that oxidatively modified carbon (OMC) material is inexpensive and highly efficient at absorbing radioactive metal cations, including cesium and strontium, toxic elements from contaminated water. It is especially efficient toward $\mathrm{Cs}^{+}$cations, the species that are among the most difficult to remove from the water. Xiong et al. (2008) used both UF and RO techniques for the removal of low level radioactive water containing plutonium. The system consists of ultrafiltration module with hollow fibre membrane and reverse osmosis module with spiral membrane. The decontamination efficiency achieves 99.94\% and the volume concentration ratio achieves 12.5 at $\mathrm{pH} 10$ for solution fed into the membrane separation system. Dulama et al. (2010) proposed to treat the waste by combining the sorption of radionuclides on natural inorganic sorbents (zeolites) with membrane filtration.

Zhu et al. (2014a, b) prepared PVA/chitosan magnetic composite beads and used for $\mathrm{Co}^{2+}$ removed from radioactive waste. The maximum sorption capacity was $14.39 \mathrm{mg} / \mathrm{g}$ at $\mathrm{pH} 6.0$ and $30^{\circ} \mathrm{C}$ according to the Langmuir model. The $-\mathrm{NH}_{4}$ and $-\mathrm{OH}$ groups played the main role in $\mathrm{Co}^{2+}$ absorption process. Magnetic chitosan bead cross-linked with

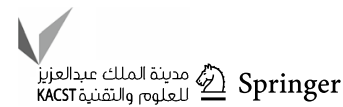


glutaraldehyde was suggested to be a promising adsorbing material for treating $\mathrm{Cs}(\mathrm{I})$-containing radioactive wastewater (Chen et al. 2016). A multifunctional flexible free-standing sodium titanate nanobelt (Na-TNB) membrane's performance was studied by Wen et al. (2016) for radiation-tainted water treatment and oil uptake. The maximum adsorption coefficient value $(\mathrm{Kd})$ for $\mathrm{Sr}^{2+}$ reached $107 \mathrm{~mL} / \mathrm{g}$. Table 14 shows the summary of the recent work for the removal of radioactive material from radioactive water/wastewater by absorption using membrane/other material.

\section{Summary and future work}

A number of advanced adsorbents, including nanostructured metal oxides, carbon nanotubes, porous boron nitride nanosheets and porous graphene have been developed recently to enhance adsorption capacity, selectivity and regeneration ability. These nanostructured adsorbents have attracted much attention as one of nanotechnology applications. However, nanoparticles cannot be packed in a column due to the high pressure drop they cause. Hence, nanoparticles have to be either embedded in or coated on the surface of larger particles, by which the merit of nanoparticles is largely compromised. Incorporation of nanoparticles in nanofibrous membrane can circumvent this problem due to nanofiber's large surface area and porosity, which, respectively, allow high adsorption and high filtration capacity. When embedded in nanofibers, however, adsorption efficiency of nanoparticles is significantly diminished. A technique should be developed to attach nanoparticles to the nanofiber surface, while preventing the leaching of nanoparticles during filtration.

Another challenge is to establish an appropriate mathematical model for MA operation. Currently, in most MA works, adsorption isotherm and kinetics are the only parameters to characterize MA membranes. A set of more powerful MA membrane characterization parameters should be found to optimize the membrane defunctionalized graphene as a nanostructured membrane for removal of copper and mercury from aqueous solution: a molecular dynamics simulation study.

Table 14 Summary of the recent work for the removal of radioactive material from radioactive water/wastewater by absorption using membrane/ other material

\begin{tabular}{|c|c|c|c|}
\hline Membrane & Removal of (radioactive ions) & From & References \\
\hline $\begin{array}{l}\text { Membrane of MST and CST membranes } \\
\text { with three support materials PTFE, PE } \\
\text { and cellulose. }\end{array}$ & $\mathrm{Sr}, \mathrm{Cs}$ & Aqueous solution & Oji et al. (2009) \\
\hline CST & $\mathrm{Co}$ and $\mathrm{Sr}$ from & Laundry wastewater & Weerasekara et al. (2013) \\
\hline Combining UF and Ro & $\mathrm{Pu}$ & Low level radioactive water & Xiong et al. (2008) \\
\hline PVA/chitosan & $\mathrm{Co}^{2+}$ & Radioactive water & Zhu et al. $(2014 a, b)$ \\
\hline \multicolumn{4}{|l|}{ Other material } \\
\hline PB coated magnetic NPTs & Cs & Radioactive waste & Jang et al. (2014) \\
\hline Carbon- $\gamma-\mathrm{Fe}_{2} \mathrm{O}_{3}$ & $\mathrm{Co}^{2+}, \mathrm{Sr}^{2+}$ and $\mathrm{Cs}^{+}$ & $\begin{array}{l}\text { Radioactive material emitted by the } \\
\text { Fukushima Daiichi nuclear power plant } \\
\text { accident }\end{array}$ & Yamaguchi et al. (2014) \\
\hline AMP-PAN beads & $\mathrm{Co}^{2+}, \mathrm{Sr}^{2+}$ and $\mathrm{Cs}^{+}$ & Waste water from nuclear plants & Park et al. (2010) \\
\hline OBPX22C6/mesoporous silica & $\mathrm{Cs}+$ & Radioactive water & Awual et al. (2016) \\
\hline $\mathrm{Ag}_{2} \mathrm{O} / \gamma-\mathrm{Al}_{2} \mathrm{O}_{3}$ & Radioactive iodine & Water & Bo (2012) \\
\hline HAP & ${ }^{90} \mathrm{Sr}$ & Aqueous solution & Nishiyama et al. (2016) \\
\hline IE911 & Cs and $\mathrm{Sr}$ & HSW & Lee et al. (2015) \\
\hline $\begin{array}{l}\text { Particles } \mathrm{Fe}_{3} \mathrm{O}_{4} \text { and } \\
\text { bis(trimethoxysilylpropyl)amine }\end{array}$ & $\mathrm{Ca}, \mathrm{Sr}$ & Water & Ye et al. (2008) \\
\hline Zeolite 4A & $\mathrm{Cs}^{+}, \mathrm{Sr}^{2+}, \mathrm{Co}^{2+}$ & Water & Fang et al. (2016) \\
\hline NKF-6 zeolite & ${ }^{63} \mathrm{Ni}$ & Water & Zhang et al. (2010) \\
\hline $\begin{array}{l}\text { Hydroxyapatite, fluorspar, calcite, } \\
\text { quartz and quartz activated by ferric } \\
\text { ions }\end{array}$ & ${ }^{18} \mathrm{~F}$ & Water & Fan et al. (2003) \\
\hline $\mathrm{OMC}$ & $\begin{array}{l}\text { Several metal cations, espe- } \\
\text { cially } \mathrm{Cs}^{+} \text {cation }\end{array}$ & Contaminated water & Khannanov et al. (2017) \\
\hline Magnetic chitosan bead glutaraldehyde & $\mathrm{Cs}^{+}$cation & Radioactive water & Chen et al. (2016) \\
\hline $\mathrm{CuFe}_{2} \mathrm{O}_{4}$ & ${ }^{90} \mathrm{Sr}$ & Radioactive water & Tu et al. (2016) \\
\hline $\mathrm{Na}-\mathrm{TNB}$ & ${ }^{90} \mathrm{Sr}^{2+},{ }^{137} \mathrm{Cs}^{+}$ & Tainted water and oil & Wen et al. (2016) \\
\hline
\end{tabular}


Open Access This article is distributed under the terms of the Creative Commons Attribution 4.0 International License (http://creativecomm ons.org/licenses/by/4.0/), which permits unrestricted use, distribution, and reproduction in any medium, provided you give appropriate credit to the original author(s) and the source, provide a link to the Creative Commons license, and indicate if changes were made.

\section{References}

Abdulgafour HI, Mohammed FM, Abdul-Majeed MA (2015) Removal elements from an industrial wastewater of refinery at different temperatures using CNTs. Int J Sci Res (IJSR) 4(12):1616-1619

Abraham J, Vasu KS, Williams CD, Gopinadhan K, Su Y, Cherian Y, Dix J, Prestat E, Haigh SJ, Grigorieva IV, Carbone P, Geim AK, Nair RR (2017) Tune sieving of ions using graphene oxide membranes. Nat Nanotechnol. https://doi.org/10.1038/nnano.2017.21

Adie AB, Okuofu CA (2012) Comparative analysis of the adsorption of heavy metals in wastewater using borrassus aethiopium and cocos nucifera. Intern J Appl Sci Technol 2(7):314-322

Adil S, Mashiatullah A, Asma M, Abid J, Ghaffar A (2014) Heavy metal removal efficiency of paper mulberry biochar and commercially available silica powder from simulated industrial wastewater. Iran J Energy Environ 5(4):446-452

Agbozu IE, Emoruwa FU (2014) Batch adsorption of heavy metals (Cu, $\mathrm{Pb}, \mathrm{Fe}, \mathrm{Cr}$, and $\mathrm{Cd}$ ) from aqueous solutions using coconut husk. Afr J Environ Sci Technol 8(4):239-246

Ahmad K, Bhatti IA, Muneer M, Iqbal M, Iqbal Z (2012) Removal of heavy metals ( $\mathrm{Zn}, \mathrm{Cr}, \mathrm{Pb}, \mathrm{Cd}, \mathrm{Cu}$ and $\mathrm{Fe}$ ) in aqueous media by calcium carbonate as an adsorbent. IJCBS 2:48-53

Algarra M, Vázquez MI, Alonso B, Casado CM, Casado J, Benavente $\mathrm{J}$ (2014) Characterization of an engineered cellulose based membrane by thiol dendrimer for heavy metals removal. Chem Eng J 253:472-477

Ali A, Ahmed A, Gad A (2016) Chemical and microstructural analyses for heavy metals removal from water media by ceramic membrane filtration. Water Sci Technol. https://doi.org/10.2166/ wst. 2016.537

Aliabadi M (2016) Removal of $\mathrm{Pb}(\mathrm{II})$ and $\mathrm{Cr}(\mathrm{VI})$ ions from aqueous solutions using chitosan/cobalt ferrite nanofibrous adsorbent. Fibers Polym 17(8):1162-1170

Aliasghar R, Aliakbar B, Alireza S, Khashayar S, Laleh A (2014) Thermodynamic investigation of $\mathrm{Pb}^{2+}$ and $\mathrm{Cd}^{2+}$ ions absorption from aqueous solutions using multi-walled carbon nanotube. Brit $\mathbf{J}$ Appl Sci Technol 4(10):1497-1508

Al-Jlil SA (2010) Removal of heavy metals from industrial wastewater by adsorption using local Bentonite clay and roasted date pits in Saudi Arabia. Trends Appl Sci Res 5:138-145

Al-Rashdi B, Somerfield C, Hilal N (2011) Heavy metals removal using adsorption and nanofiltration techniques. Sep Purif Rev 40:209-259

Amin MT, Alazba AA, Manzoor U (2014) A review of removal of pollutants from water/wastewater using different types of nanomaterials. Adv Mater Sci Eng. https://doi.org/10.1155/2014/8259 10 (Article ID 825910)

Anitha K, Namsani S, Singh JK (2015) Removal of heavy metal ions using a functionalized single-walled carbon nanotube: a molecular dynamics study. J Phys Chem A 119(30):8349-8358

Atieh MA (2011) Removal of Chromium (VI) from polluted water using carbon nanotubes supported with activated carbon. Proced Environ Sci 4:281-293

Avramescu M, Gironès M, Borneman Z, Wessling M (2003) Preparation of mixed matrix absorber membranes for protein recovery. J Membr 218(1-2):219-233
Avramescu M, Gironès M, Borneman Z, Wessling M (2008) Particleloaded hollow-fiber membrane absorbers for lysozyme separation. J Membr Sci 322(2):306-313

Awual MR, Yaita T, Miyazaki Y, Matsumura D, Shiwaku H, Taguchi $\mathrm{T}$ (2016) A reliable hybrid adsorbent for efficient radioactive cesium accumulation from contaminated wastewater. Sci Rep 6. https://doi.org/10.1038/srep19937. (Article number: 19937)

Azamat J, Khataee A, Joo SW (2014) Separation of a heavy metal from water through a membrane containing boron nitride nanotubes: molecular dynamics simulations. J Mol Model 20:2468. https:// doi.org/10.1007/s00894-014-2468-1

Azamat J, Khataee A, Joo SW (2015) Molecular dynamics simulation of trihalomethanes separation from water by functionalized nanoporous graphene under induced pressure. Chem Eng Sci 127:285-292

Babel S, Kurniawa TA (2003) Low-cost adsorbents for heavy metals uptake from contaminated water: a review. J Hazard Mater B 97:219-243

Badruddoza AZM, Shawon ZBZ, Daniel TWJ, Hidajat K, Uddin MS (2013) $\mathrm{Fe}_{3} \mathrm{O}_{4}$ /cyclodextrin polymer nanocomposites for selective heavy metals removal from industrial wastewater. Carbohyd Polym 91:322-332

Bandela NN, Babrekar MG, Jogdand OK, Kaushik G (2016) Removal of Copper from aqueous solution using local agricultural wastes as low-cost adsorbent. J Mater Environ Sci 7(6):1972-1978

Bernat X, Sánchez I, Stüber F, Bengoa C, Fortuny A, Fabregat A, Font J (2007) Removal of heavy metals by ultrafiltration. In: Proceedings of European congress of chemical engineering (ECCE-6) Copenhagen, 16-20 September 2007

Bessbousse H, Rhlalou T, Verchere JF, Lebrun L (2008) Removal of heavy metal ions from aqueous solutions by filtration with a novel complexing membrane containing poly(ethyleneimine) in a poly(vinyl alcohol) matrix. J Membr Sci 307:249-259

Bo A (2012) Development of modified inorganic adsorbents for radioactive iodine removal and biomolecule adsorption. Dissertation. Queensland University of Technology, Canada

Bobade V, Eshtiag N (2015) Heavy metals removal from wastewater by adsorption process: A review'. In: Asia Pacific Confederation of Chemical Engineering Congress 2015 (APCChE 2015), Melbourne, Australia, 27 September 1 October, pp 312-317

Bozorgpour F, Ramandi HF, Jafari P, Samadi S, Yazd SS, Aliabad M (2016) Removal of nitrate and phosphate using chitosan $/ \mathrm{Al}_{2} \mathrm{O}_{3} /$ $\mathrm{Fe}_{3} \mathrm{O}_{4}$ composite nanofibrous adsorbent: comparison with chitosan $/ \mathrm{Al}_{2} \mathrm{O}_{3} / \mathrm{Fe}_{3} \mathrm{O}_{4}$ beads. Int J Biol Macromol A 93:557-565

Carpenter AW, de Lannoy CF, Wiesner MR (2015) Cellulose nanomaterials in water treatment technologies. Environ Sci Technol 49(9):5277-5287

Chandra V, Park J, Chun Y, Lee JW, Hwang IC, Kim KS (2010) Waterdispersible magnetite-reduced graphene oxide composites for arsenic removal. CS Nano 4(7):3979-3986

Chatterjee S, De S (2014) Adsorptive removal of fluoride by activated alumina doped cellulose acetate phthalate (CAP) mixed matrix membrane. Sep Purif Technol 125:223-238

Chen YW, Wang JL (2016) Removal of cesium from radioactive wastewater using magnetic chitosan beads cross-linked with glutaraldehyde. Nucl Sci Tech. https://doi.org/10.1007/s413 65-016-0033-6

Chen JH, Li GP, Liu L, Ni JC, Wu WB, Lin JM (2010) Cr(III) ionic imprinted polyvinyl alcohol/sodium alginate (PVA/SA) porous composite membranes for selective adsorption of $\mathrm{Cr}$ (III) ions. Chem Eng J 165(2):465-473

Chen X, Zhou S, Zhang L, You T, Xu F (2016) Adsorption of heavy metals by graphene oxide/cellulose hydrogel prepared from $\mathrm{NaOH} / \mathrm{urea}$ aqueous solution. Materials 9:582-589

Chooaksorn W, Nitisoravut R (2015) Heavy metal removal from aqueous solutions by chitosan coated ceramic membrane. In: 4th

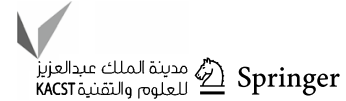


international conference on informatics, environment, energy and applications volume (2015) 82 of IPCBEE. https://doi. org/10.7763/ipcbee

Chougui A, Zaiter K, Belouatek A, Asli B (2014) Heavy metals and color retention by a synthesized inorganic membrane. Arab J Chem 7(5):817-822

Cong HP, Ren XC, Wang P, Yu SH (2012) Macroscopic multifunctional graphene-based hydrogels and aerogels by a metal ion induced self-assembly process. ACS Nano 6(3):2693-2703

Crini G (2005) Recent developments in polysaccharide-based materials used as adsorbents in wastewater treatment, review. Prog Polym Sci 30:38-70

Crini G, Crini NM, Fatin-Rouge N, Deon S, Fievet P (2017) Metal removal from aqueous media by polymer-assisted ultrafiltration with chitosan. Arab J Chem 10(2):S3826-S3839

Cui L, Wang Y, Gao L, Hu L, Wei Q (2015) Removal of Hg(II) from aqueous solution by resin loaded magnetic b-cyclodextrin bead and graphene oxide sheet: synthesis, adsorption mechanism and separation properties. J Colloid Interface Sci 456:42-49

Dessouki AM, Hegazy EA, EL-Korashy SA, EL-Kelesh NA (2000) Removal of some heavy metals from wastewater using radiationadsorption method. In: Seventh conference of nuclear sciences and applications 6-10 February 2000, Cairo, Egypt

Diallo MS, Christie S, Swaminathan P, Balogh L, Shi XY, Um W, Papelis C, Goddard WA, Johnson JH (2004) Dendritic chelating agents. 1. $\mathrm{Cu}$ (II) binding to ethylene diamine core poly(amidoamine) dendrimers in aqueous solutions. Langmuir 20:2640-2651

Diallo MS, Christie S, Swaminathan P, Johnson JH, Goddard WA (2005) Dendrimer enhanced ultrafiltration. 1. Recovery of $\mathrm{Cu}(\mathrm{II})$ from aqueous solutions using PAMAM dendrimers with ethylene diamine core and terminal NH2 groups. Environ Sci Technol 39:1366-1377

Dong Q, Liu JS, Song L, Shao GQ (2011) Novel zwitterionic inorganicorganic hybrids: synthesis of hybrid adsorbents and their applications for $\mathrm{Cu}^{2+}$ removal. J Hazard Mater 186(2-3):1335-1342

Doong RA, Chiang LF (2008) Coupled removal of organic compounds and heavy metals by titanate/carbon nanotube composites. Water Sci Technol 58(10):1985-1992

Dorraji MS, Mirmohseni A, Tasselli F, Criscuoli A, Carraro M, Gros S, Figoli A (2014) Preparation, characterization and application of iron(III)-loaded chitosan hollow fiber membranes as a new bio-based As (V) sorbent. J Polym Res 21:399-402

Dulama M, Deneanu N, Pavelescu M, Pasre L (2009) Combined radioactive liquid waste treatment processes involving inorganic sorbents and micro/ultrafiltration. Rom J Phys 54:851-859

Dulama M, Deneanu N, Dulama CN, Pavelescu M (2010) Application of indigenous inorganic sorbents in combination with membrane technology for treatment of radioactive liquid waste from decontamination processes. Radiochim Acta 98:413-420

Dwivedi AK, Rajput DPS (2014) Studies on adsorptive removal of heavy metal $(\mathrm{Cu}, \mathrm{Cd})$ from aqueous solution by tea waste adsorbent. J Ind Pollut Control 30(1):85-90

Fan X, Parker DJ, Smith MD (2003) Adsorption kinetics of fluoride on low cost material. Water Res 37:4929-4937

Fang XH, Fang F, Lu CH, Zheng L (2016) Removal of $\mathrm{Cs}^{+}, \mathrm{Sr}^{2+}$, and $\mathrm{Co}^{2+}$ ions from the mixture of organics and suspended solids aqueous solutions by zeolites. Nucl Eng Technol 49(3):555-561

Fatin-Rouge N, Dupont A, Vidonne A, Dejeu J, Fievet P, Foissy A (2006) Removal of some divalent cations from water by membrane-filtration assisted with alginate. Water Res 40:1303-1309

Firdhouse MJ, Lalitha P (2016) Nanosilver-decorated nanographene and their adsorption performance in waste water treatment. Bioresour Bioprocess 3:12-27
Franklin B (1746) When the well is dry, we know the worth of water. Poor Richard's Almanac. http://www.notablequotes.com/f/fran klin_benjamin_v.html

Fu F, Wang Q (2011) Removal of heavy metal ions from wastewaters: a review. J Environ Manag 92:407-418

Gehrke I, Geiser A, Somborn-Schulz A (2015) Innovations in nanotechnology for water treatment. Nanotechnol Sci Appl 8:1-17

Ghaemi A, Torab-Mostaedi M, Ghannadi-Maragheh M (2011) Characterizations of strontium(II) and barium(II) adsorption from aqueous solutions using dolomite powder. J Hazard Mater 190(1-3):916-921

Giraldo L, Erto A, Moreno-Piraján JC (2013) Magnetite nanoparticles for removal of heavy metals from aqueous solutions: synthesis and characterization. Adsorption 19(2):465-474

Gohari RJ, Lau WJ, Matsuura T, Ismail AF (2013) Fabrication and characterization of novel PES/Fe-Mn binary oxide UF mixed matrix membrane for adsorptive removal of As(III) from contaminated water solution. Sep Purif Technol 118:64-72

Gollavelli G, Chang C, Ling YC (2013) Facile synthesis of smart magnetic graphene for safe drinking water: heavy metal removal and disinfection control. ACS Sust Chem Eng 1:462-472

Gopalakrishnan A, Krishnan R, Thangavel S, Venugopal G, Kim SJ (2015) Removal of heavy metal ions from pharma-effluents using graphene-oxide nanosorbents and study of their adsorption kinetics. J Ind Eng Chem 30:14-19

Gupta VK, Agarwal S, Saleh TA (2011) Synthesis and characterization of alumina-coated carbon nanotubes and their application for lead removal. J Hazard Mater 185(1):17-23

Habiba U, Afifi AM, Salleh A, Ang BC (2017) Chitosan/(polyvinyl alcohol)/zeolite electrospun composite nanofibrous membrane for adsorption of $\mathrm{Cr}^{6+}, \mathrm{Fe}^{3+}$ and $\mathrm{Ni}^{2+}$. $\mathrm{J}$ Hazar Mater 322A:182-194

Haider S, Park SY (2009) Electrospin chitosan nanofiber for the separation of $\mathrm{Cu}(\mathrm{II})$ and $\mathrm{Pb}(\mathrm{II})$ ions from aqueous solution. J Membr Sci 328:90-96

Han Y, Xu Z, Gao C (2013) Ultrathin graphene nanofiltration membrane for water purification. Adv Funct Mater 23(29):3693-3700

He ZY, Nie HL, Branford-White C, Zhu LM, Zhou YT, Zheng Y (2008) Removal of $\mathrm{Cu}^{2+}$ from aqueous solution by adsorption onto a novel activated nylon-based membrane. Bioresour Technol 99:7954-7958

He J, Matsuura T, Chen JP (2014) A novel Zr-based nanoparticleembedded PSF blend hollow fiber membrane for treatment of arsenate contaminated water: material development, adsorption and filtration studies, and characterization. J Membr Sci 452:433-445

He K, Chen Y, Tang Z, Hu Y (2016) Removal of heavy metal ions from aqueous solution by zeolite synthesized from fly ash. Environ Sci Pollut Res 23(3):2778-2788

Hegazi HA (2013) Removal of heavy metals from wastewater using agricultural and industrial wastes as adsorbents. HBRC J 9(3):276-282

Hermassi M, Valderrama C, Gibert O, Moreno N, Font O, Querol $\mathrm{X}$, Batis NH, Cortina JL (2016) Integration of powdered Caactivated zeolites in a hybrid sorption-membrane ultrafiltration process for phosphate recovery. Ind Eng Chem Res 55(21):6204-6212

Hua M, Zhang S, Pan B, Zhang W, Lv L, Zhang Q (2012) Heavy metal removal from water/wastewater by nanosized metal oxide: a review. J Hazard Mater 211-212:317-331

Huang CP, Tsang MW, Hsieh YS (1985) The removal of cobalt(II) from water by activated carbon. AIChE Sympos Ser Sep Heavy Metals Other Trace Contam 81(243):85-98 
Huang ZH, Zheng X, Lv W, Wang M, Yang H, Kang F (2011) Adsorption of lead(II) ions from aqueous solution on low-temperature exfoliated graphene nanosheets. Langmuir 27(12):7558-7562

Ibrahimi MM, Sayyadi AS (2015) Application of natural and modified zeolites in removing heavy metal Cations from aqueous media: an overview of including parameters affecting the process. Int $\mathrm{J}$ Geol Agric Environ Sci 3(2):7

Ibigbami TB, Dawodu FA, Akinyeye OJ (2016) Removal of heavy metals from pharmaceutical industrial wastewater effluent by combination of adsorption and chemical precipitation methods. Am J Appl Chem 4(1):24-32

Jaafar AD (2012) Removal of copper(II) from wastewater using modified carbon nanotubes. Dissertation. University of Technology Baghdad-Iraq

Jang SC, Hong SB, Yang HM, Lee KW, Moon JK, Seo BK, Huh YS, Roh C (2014) Removal of radioactive cesium using prussian blue (PB) magnetic nanoparticles. Nanomaterials 4:894-901

Jiménez-Castañeda ME, Medina DI (2017) Use of surfactant-modified zeolites and clays for the removal of heavy metals from water. Water 9:235. https://doi.org/10.3390/w9040235

Kadirvelu K, Thamaraiselvi K, Namasivaya C (2001) Removal of heavy metals from industrial wastewaters by adsorption onto activated carbon prepared from an agricultural solid waste. Bioresour Technol 76:63-65

Kandah MI, Meunier JL (2007) Removal of nickel ions from water by multi-walled carbon nanotubes. J Hazard Mater 146(1-2):283-2880

Karim MR (2015) Nanofiber membranes for heavy metals removal from waste waters. King Saud University December 2015, pp $28-29$

Katsoyiannis IA, Zouboulis AI (2002) Removal of arsenic from contaminated water sources by sorption onto iron-oxide-coated polymeric materials. Water Res 36(20):5141-5155

Khan I, Abbas A, Almer A, Ma A (2016) Heavy metal removal from aqueous solution by advanced carbon nanotubes: critical review of adsorption applications. Sep Purif Technol 157:141-161

Khannanov A, Nekljudov VV, Gareev B, Kiiamov A, Tour JM, Dimieva AM (2017) Oxidatively modified carbon as efficient material for removing radionuclides from water. Carbon 115:394-401

Kim J, der Bruggen B (2010) The use of nanoparticles in polymeric and ceramic membrane structures: review of manufacturing procedures and performance improvement for water treatment. Environ Pollut 158(7):2335-2349

Klaassen R, Feron P, Jansen A (2008) Membrane contactor applications. Desalination 224:81-87

Kosa SA, Al-Zhrani G, Salam MA (2012) Removal of heavy metals from aqueous solutions by multi-walled carbon nanotubes modified with 8-hydroxyquinoline. Chem Eng J 181-182:159-168

Krason J, Pietrzak R (2016) Membranes obtained on the basis of cellulose acetate and their use in removal of metal ions from liquid phase. Pol J Chem Technol 18(2):104-110

Kumar R, Chawla J, Kaur I (2015) Removal of cadmium ion from wastewater by carbon-based nano sorbents: a review. J Water Health 13(1):18-33

Kunin R (1976) The use of macroreticular polymeric adsorbents for the treatment of waste effluents. Pure Appl Chem 46:205-211

Kurniawan TA, Chan GYS, Lo WH, Babel S (2006) Comparisons of low-cost adsorbents for treating wastewaters laden with heavy metals. Sci Total Environ 366(2-3):409-426

Kyzas GJ, Deliyanni EA, Matis KA (2014) Graphene oxide and its application as an adsorbent for wastewater treatment. J Chem Technol Biotechnol 89:196-205

Lakherwa D (2014) Adsorption of heavy metals: a review. Int J Environ Res Dev 4(1):2249-3131

Lasheen MR, El-Sherif IY, Sabry DY, El-Wakeel ST, El-Shahat MF (2015) Removal of heavy metals from aqueous solution by multiwalled carbon nanotubes: equilibrium, isotherms, and kinetics. Desalin Water Treat 53(13):3521-3530

Lee J, Chae HR, Won YJ, Lee K, Lee CH, Lee HH, Kim IC, Lee J (2013) Graphene oxide nanoplatelets composite membrane with hydrophilic and antifouling properties for wastewater treatment. J Membr Sci 2013:223-230

Lee EH, Lee KY, Kim KW, Kim IS, Chung DY, Dong-Yong JK, Moon JK (2015) Removal of Cs by adsorption with IE911 (Crystalline silicotitanate) from high-radioactive seawater waste. J Nucl Fuel Cycle Waste Technol 13(3):171-180

Li Y, Liu F, Xia B, Du Q, Zhang P, Wang D, Wang Z, Xia Y (2010) Removal of copper from aqueous solution by carbon nanotube/ calcium alginate composites. J Hazard Mater 177:876-880

Li B, Zhou F, Huang K, Mei S, Zhou Y, Jing T (2016) Highly efficient removal of lead and cadmium during wastewater irrigation using a polyethylenimine-grafted gelatin sponge. Sci Rep 6. https://doi. org/10.1038/srep33573. (Article number: 33573)

Li L, Li Y, Yang C (2016b) Chemical filtration of Cr(VI) with electrospun chitosan nanofiber membranes. Carbohyd Polym 140:299-307

Liu JS, Wang X (2013) Novel silica-based hybrid adsorbents: lead(II) adsorption isotherms. Sci World J 2013:6. https://doi. org/10.1155/2013/897159. (Article ID 897159)

Liu J, Zhao Z, Jiang G (2008) Coating Fe3O4 magnetic nanoparticles with humic acid for high efficient removal of heavy metals in water. Environ Sci Technol 42(18):6949-6954

Liu J, Song L, Shao G (2011) Novel zwitterionic inorganic-organic hybrids: kinetic and equilibrium model studies on $\mathrm{Pb}^{2+}$ removal from aqueous solution. J Chem Eng Data 56(5):2119-2127

Liu Y, Ma H, Liu B, Hsiao BS, Chu B (2015) High-performance nanofibrous membrane for removal of $\mathrm{Cr}(\mathrm{VI})$ from contaminated water. J Plast Film Sheet 31(4):379-400

Ma H, Hsiao BS, Chu B (2013) Electrospun nanofibrous membrane for heavy metal ion adsorption. Curr Org Chem 17(13):1361-1370

Ma L, Dong X, Chen M, Zhu L, Wang C, Yang F, Dong Y (2017) Fabrication and water treatment application of carbon nanotubes (CNTs)-based composite membranes: a review. Membranes $7(1): 16-37$

Madadrang CJ, Kim HY, Gao G, Wang N, Zhu J, Feng H, Gorring M, Kasner ML, Hou S (2012) Adsorption behavior of EDTAgraphene oxide for $\mathrm{Pb}(\mathrm{II})$ removal. ACS Appl Mater Interfaces 4(3):1186-1193

Mahdavi S, Jalali M, Afkhami A (2012) Removal of heavy metals from aqueous solutions using $\mathrm{Fe}_{3} \mathrm{O}_{4}, \mathrm{ZnO}$ and $\mathrm{CuO}$ nanoparticles. In: Diallo MS, Fromer NA, Jhon MS (eds) Nanotechnology for sustainable development. Springer, Cham, pp 171-188

Mahmud HNME, Huq AKO, Yahya R (2016) The removal of heavy metal ions from wastewater/aqueous solution using polypyrrole-based adsorbents: a review. RSC Adv 18:14778-14791

Malik DS, Jain CK, Yadav A (2016) Removal of heavy metals from emerging cellulosic low-cost adsorbents: a review. Appl Water Sci. https://doi.org/10.1007/s13201-016-0401-8

Mavrov V, Erwe T, Blocher C, Chmiel H (2003) Study of new integrated processes combining adsorption, membrane separation and flotation for heavy metal removal from wastewater. Desalination 157:97-104

Meena AK, Mishra GK, Rai PK, Rajagopal C, Nagar PN (2005) Removal of heavy metal ions from aqueous solutions using carbon aerogel as an adsorbent. J Hazard Mater 122:161-170

Meidanchi A, Akhavan O (2014) Superparamagnetic zinc ferrite spinel-graphene nanostructures for fast wastewater purification. Carbon 69:230-238

Mishra AK, Ramaprabhu S (2011) Functionalized graphene sheets for arsenic removal and desalination of sea water. Desalination 282:39-45

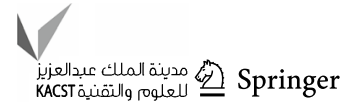


Moayyeri N, Saeb K, Biazar E (2013) Removal of heavy metals (lead, cadmium, zinc, nickel and iron) from water by bioceramic absorbers of hydroxy-apatite microparticles. Int J M Ar Sci Eng Winter 3(1):13-16

Moodley K, Singh R, Musapatika ET, OnyangoI MS, Ochieng A (2011) Removal of nickel from wastewater using an agricultural adsorbent. Water SA 37(1):41-46

Mubarak NM, Sahu JN, Abdullah EC, Jayakumar NS (2014) Removal of heavy metals from wastewater using carbon nanotubes. Sep Purif Rev 43(4):311-338

Mubarak NM, Thobashinni M, Abdullah EC, Sahu JN (2016) Comparative kinetic study of removal of $\mathrm{Pb}^{2+}$ ions and $\mathrm{Cr}^{3+}$ ions from waste water using carbon nanotubes produced using microwave heating. J Carbon Res C 2(1):7-23

Mukherjee R, Bhunia P, De S (2016) Impact of graphine oxide on removal of heavy metals using mixed matrix membrane. Chem Eng J 292:284-297

Munter R (2013) Technology for the removal of radionuclides from natural water and waste management: state of the art. Proc Estonian Acad Sci 62(2):22-132

Muthulakshmi AN, Anuradha J (2015) Removal of cadmium ions from water/waste water using chitosan-a review. RRJEAESI Integrated Waste management and Energy Recovery- S1, 2015. (e-ISSN:2320-0189, p- ISSN:2347-2308)

Nasef MM, Yahaya AH (2009) Adsorption of some heavy metal ions from aqueous solutions on Nafion 117 membrane. Desalination 249(2):677-681

Nassar NN, Arar MN, Ghanim MMA, Dwekat MS, Sawalha HH (2014) Treatment of olive mill based wastewater by means of magnetic nanoparticles: Decolourization dephenolization and COD removal. Environ Nanotechnol Monit Manag 1:14-23

Nishiyama Y, HanafusaT Yamashita J, Yamamoto Y, Ono T (2016) Adsorption and removal of strontium in aqueous solution by synthetic hydroxyapatite. J Radioanal Nucl Chem 307:1279-1285

Ojedokun AT, Bello OS (2016) Sequestering heavy metals from wastewater using cow dung. Water Resour Ind 13:7-13

Oji LN, Martin KB, Hobbs DT (2009) Development of prototype titanate ion-exchange loaded-membranes for strontium, cesium and actinide decontamination from aqueous media. J Radioanal Nucl Chem 279:847-854

Okoya AA, Akinyele AB, Ofoezie IE, Amuda OS, Alayande OS, Makinde OW (2014) Adsorption of heavy metal ions onto chitosan grafted cocoa husk char. Afr J Pure Appl Chem 8(10):147-161

Oliveira CR, Rubio J (2007) Adsorption of ions onto treated natural zeolite. Mat Res 10(4):407-412

Onundi YB, Mamun AA, Al Khatib MF, Al Saadi MA, Suleyman AM (2011) Heavy metals removal from synthetic wastewater by a novel nano-size composite adsorbent. Int J Environ Sci Technol 8(4):799-806

Ouki SK, Kavannagh M (1997) Performance of natural zeolites for treatment of mixed metal contaminated effluents. Waste Manag Res 15:383-394

Padmavathi R, Minnoli M, Sangeetha D (2014) Removal of heavy metal ions from waste water using anion exchange polymer membranes. Int J Plast Technol 18:88-99

Pang Y, Zeng G, Tang L, Zhang Y, Liu Y, Lei X, Li Z, Zhang J, Xie G (2011) PEI-grafted magnetic porous powder for highly effective adsorption of heavy metal ions. Desalination 281:278-284

Park Y, Lee YC, Shin WS, Choi SJ (2010) Removal of cobalt, strontium and cesium from radioactive laundry wastewater by ammonium molybdophosphate-polyacrylonitrile (AMP-PAN). Chem Eng J 162:685-695

Phadtare MJ, Patil ST (2015) Removal of heavy metal from industrial waste water. Int J Adv Eng Res Studies/IV/III/April-June, 2015/04-08
Pillay K, Cukrowska EM, Coville NJ (2009) Multi-walled carbon nanotubes adsorbents for the removal of parts per billion levels of hexavalent chromium from aqueous solution. J Hazard Mater 166:1067-1075

Predescu A, Nicolae A (2012) Adsorption of $\mathrm{Zn}, \mathrm{Cu}$ and Cd from waste waters by means of maghemite nanoparticles. U PB Sci Bull Ser B 74(1):255-264

Pyrzyńska K, Bystrzejewski M (2010) Comparative study of heavy metal ions sorption onto activated carbon, carbon nanotubes, and carbon-encapsulated magnetic nanoparticles. Colloids Surf A 3629(1-3):102-109

Ramalingam SJ, Khan TH, Pugazhlenthi M, Thirumurugan V (2013) Removal of $\mathrm{Pb}(\mathrm{II})$ and $\mathrm{Cd}(\mathrm{II})$ ions from industrial waste water using calotropis procera roots. Int J Eng Sci Invent 2(4):1-6

Ramanjaneyulu PS, Singh P, Sayi YS, Chawla HM, Ramakumar KL (2010) Ion selective electrode for cesium based on 5-(4 -nitrophenylazo)25,27-bis(2-propyloxy)26,28-dihydroxycalix arene. J Hazard Mater 175:1031-1036

Rana D, Matsuura T, Kassim MA, Ismail AF (2013) Radioactive decontamination of water by membrane processes-a review. Desalination 321:77-92

Rana K, Shah M, Limbachiy N (2014) Adsorption of copper Cu (2+) metal ion from waste water using sulphuric acid treated sugarcane. IJAERS 1(1):55-59

Rao GP, Lu C, Su F (2007) Sorption of divalent metal ions from aqueous solution by carbon nanotubes: a review. Sep Purif Technol 58:224-231

Ritchie SMC, Bachas LG, Olin T, Sikdar SK, Bhattacharyya D (1999) Surface modification of silica- and cellulose-based microfiltration membranes with functional polyamino acids for heavy metal sorption. Langmuir 15(19):6346-6357

Robinson B (2017) Graphene sieve turns seawater into drinking water. Manchester University news April 3 2017. http://www.manchest er.ac.uk/discover/news/graphene-sieve-turns-seawater-into-drin king-water. Internet April 2017

Rosell A (2015) Purification of radioactive waste water using a ceramic membrane. Dissertation. Chalmers University of Technology, Gothenburg, Sweden

Ruthiraan M, Mubarak NM, Thines RK, Abdullah EC, Sah JN, Jayakumar NS, Ganesan P (2015) Comparative kinetic study of functionalized carbon nanotubes and magnetic biochar for removal of $\mathrm{Cd}^{2+}$ ions from wastewater. Korean J Chem Eng 32(3):446-457

Saber-Samandari S, Gazi M (2013) Removal of mercury(II) from aqueous solution using chitosan-graft-polyacrylamide semi-IPN hydrogels. Sep Sci Technol 48(9):1382-1390

Sabo Š, Bakalár T, Búgel M, Pavolová H (2015) Removal of heavy metals from waste water using a hybrid membrane process. Geol Geophys Environ 41(1):130-131

Sadegh H, Ghoshekandi RS, Masjedi A, Mahmoodi Z, Kazemi M (2016) A review on carbon nanotubes adsorbents for the removal of pollutants from aqueous solutions. Int J Nano Dimens 7(2):109-120

Saffaj N, Loukili H, Younssi SA, Albizane A, Bouhria M, Persin M, Larbot A (2004) Filtration of solution containing heavy metals and dyes by means of ultrafiltration membranes deposited on support made of Moroccan clay. Desalination 168:301-306

Said KAM, George GG, Alipah NAM, Ismail NZ, Jama'in RL (2015) Effect of activated carbon in PSF-PEI-Ag symmetric membrane. MATEC Web of Conferences 87 (2017) 03008 ENCON 2016. https://doi.org/10.1051/matecconf/20178703008

Saleh TA, Gupta VK (2012) Column with CNT/magnesium oxide composite for lead(II) removal from water. Environ Sci Pollut Res 19(4):1224-1228

Senna MMH, Abdel-Moneam YK, Gamal OA, Alarifi A (2013) Preparation of membranes based on high-density polyethylene 
graft copolymers for phosphate anion removal. J Ind Eng Chem 19(1):48-55

Sharma YC, Srivastava V, Singh VK, Kaul SN, Weng CH (2009) Nanoadsorbents for the removal of metallic pollutants from water and wastewater. Environ Technol 30(6):583-609

Sheet I, Kabbani A, Holail H (2014) Removal of heavy metals using nanostructured graphite oxide, silica nanoparticles and silica/ graphite oxide composite. Energy Proced 50:30-138

Shooto ND, Wankasi D, Sikhwivhilu LM, Dikio ED (2016) Modified electro-spun polyvinyl alcohol nanofibers used as super adsorbing material for lead ions in aqueous solution. J Resid Sci Technol 13(3):233-242

Sun P, Zhu M, Wang K, Zhong M, Wei J, Wu D, Xu Z, Zhu H (2013) Selective ion penetration of graphene oxide membranes. ACS Nano 7(1):428-437

Sharadqah S, Taamneh Y (2016) The removal of heavy metals from aqueous solution using natural Jordanian zeolite. Appl Water Sci. https://doi.org/10.1007/s13201-016-0382-7

Taman R, Ossman ME, Mansour MS, Farag HA (2015) Metal oxide nano-particles as an adsorbent for removal of heavy Metals. $\mathrm{J}$ Adv Chem Eng 5:125. https://doi.org/10.4172/advanced-chem ical-engineering. 1000125

Tian Y, Wu M, Liu R, Li Y, Wang D, Tan J, Wu R, Huan Y (2011) Electrospun membrane of cellulose acetate for heavy metal ion adsorption in water treatment. Carbohyd Polym 83:743-748

Tijani N, Ahlafi H, Smaihi M, Mansouri AE (2013) Preparation and characterization of $\mathrm{NaA}$ zeolite membranes and its application for removal of heavy metals. Mediter J Chem 2(3):484-492

Tofighy MA, Mohammad T (2011) Adsorption of divalent heavy metal ions from water using carbon nanotube sheets. J Hazard Mater 185(1):140-147

Tripathi A, Ranjan MR (2015) Heavy metal removal from wastewater using low cost adsorbents. J Bioremed Biodeg 6:315-320

Tu YJ, You CF, Zhang Z, Duan Y, Fu J, Xu DD (2016) Strontium removal in seawater by means of composite magnetic nanoparticles derived from industrial sludge. Water. https://doi. org/10.3390/w8080357

Varma S, Sarode D, Wakale S, Bhanvass BA, Deosarkar MP (2013) Removal of nickel from waste water using graphene nanocomposite. Int J Chem Phys Sci 2. (ISSN:2319-6602)

Vasudevan S, Lakshmi J (2012) The adsorption of phosphate by graphene from aqueous solution. RSC Adv 2(12):5234-5242

Vélez E, Campillo GE, Morales G, Hincapié C, Osorio J, Arnache O, Uribe JI, Jaramillo F (2016) Mercury removal in wastewater by iron oxide, nanoparticles. J Phys Conf Ser 687:012050

Vieira RS, Beppu MM (2005) Mercury ion recovery using natural and crosslinked chitosan membranes. Adsorption 11:731-736

Vieira RS, Beppu MM (2006) Dynamic and static adsorption and desorption of $\mathrm{Hg}(\mathrm{II})$ ions on chitosan membranes and spheres. Water Res 40(8):1726-1734

Vilela D, Parmar J, Zeng Y, Zhao Y, Sánchez S (2016) Graphenebased microbots for toxic heavy metal removal and recovery from water. Nano Lett 16(4):2860-2866

Vinodhini PA, Sudha PN (2016) Removal of heavy metal chromium from tannery effluent using ultrafiltration membrane. Text Cloth Sustain. https://doi.org/10.1186/s40689-016-0016-3

Wan MW, Kan CC, Rose BD, Dalida MLP (2010) Adsorption of copper(II) and lead(II) ions from aqueous solution on chitosancoated sand. Carbohyd Polym 80:891-899

Wang HJ, Zhou AL, Peng F, Yu H, Yang J (2007) Mechanism study on adsorption of acidified multiwalled carbon nanotubes to $\mathrm{Pb}(\mathrm{II})$. J Colloid Interface Sci 316:277-283

Wang X, Guo Y, Yang L, Han M, Zhao J, Cheng X (2012) Nanomaterials as sorbents to remove heavy metal ions in wastewater treatment. J Environ Anal Toxicol 2:154. https://doi. org/10.4172/2161-0525.1000154
Wang R, Guan S, Sato A, Wang X, Wang Z, Yang R, Hsiao BS, Chu B (2013) Nanofibrous microfiltration membranes capable of removing bacteria, viruses and heavy metal ions. J Membr Sci 446:376-382

Wang X, Song L, Yang F, He J (2016) Investigation of phosphate adsorption by a polyethersulfone-type affinity membrane using experimental and DFT methods. Desalin Water Treatm 57(52):25036-25056

Wang W, Wang Z, Liu J, Zhang Z, Sun L (2017) Single-step one-pot synthesis of graphene foam/ $/ \mathrm{TiO}_{2}$ nanosheet hybrids for effective water treatment. Sci Rep. https://doi.org/10.1038/srep4375 5 (Article number: 43755)

Weerasekara NA, Choo KH, Choi SJ (2013) Metal oxide enhanced microfiltration for the selective removal of $\mathrm{Co}$ and $\mathrm{Sr}$ ions from nuclear laundry wastewater. J Membr Sci 447:87-95

Wen T, Zhao Z, Shen C, Li J, Tan X, Zeb A, Wang X, Xu AW (2016) Multifunctional flexible free-standing titanate nanobelt membranes as efficient sorbents for the removal of radioactive $90 \mathrm{Sr}^{2+}$ and $137 \mathrm{Cs}^{+}$ions and oils. Sci Rep 6. https://doi. org/10.1038/srep20920. (Article number 20920)

Williams M (2017) Treated carbon pulls radioactive elements from water. January 19, 2017, Posted in: Current News. http://news .rice.edu/2017/01/19/treated-carbon-pulls-radioactive-elem ents-from-water-2/

Wingenfelder U, Hansen C, Furrer G, Schulin R (2015) Removal of heavy metals from mine waters by natural zeolites. Environ Sci Technol 39:4606-4613

Wu SJ, Li ET, Wu YN, Xu R, Li GT (2010) Preparation of novel poly(vinyl alcohol)/ $/ \mathrm{SiO}_{2}$ composite nanofiber membranes with mesostructure and their application for removal of $\mathrm{Cu}^{2+}$ from waste water. Chem Commun 46:1694-1696

Xiong ZH, Fan XH, Luo DL, Wang T, Chen Q (2008) Treatment of simulated plutonium-containing wastewater by ultrafiltrationreverse osmosis technology. J Nucl Radiochem 30:142-145

Taherian F, Marcon V, van der Vegt NF, Leroy F (2013) What is the contact angle of water on graphene? Langmuir 29:1457-1465

Yaghmaeian K, Mashizi RK, Nasseri S, Mahvi AH, Alimohammadi M, Nazmara S (2015) Removal of inorganic mercury from aquatic environments by multi-walled carbon nanotubes. J Environ Health Sci Eng 13:55-64

Yamaguchi D, Furukawa K, Takasuga M, Watanabe K (2014) A magnetic carbon sorbent for radioactive material from the Fukushima nuclear accident. Sci Rep. https://doi.org/10.1038 /srep06053 (Article number: 6053)

Yang R, Su Y, Aubrecht KB, Wang X, Ma H, Grubbs RB, Hsiao BS, Chu B (2015a) Thiol-functionalized chitin nanofibers for As(III) adsorption. Polymer 60:9-17

Yang RX, Wang TT, Deng WQ (2015b) Extraordinary capability for water treatment achieved by a perfluorous conjugated microporous polymer. Sci Rep. https://doi.org/10.1038/srep10155

Ye X, Liu T, Lia Liu H, Wu Z (2008) Comparison of strontium and calcium adsorption onto composite magnetic particles derived from $\mathrm{Fe}_{3} \mathrm{O}_{4}$ and bis(trimethoxysilylpropyl)amine. Colloids Surf A 2008:21-27

Yoo H, Kwak SY (2013) Surface functionalization of PTFE membranes with hyperbranchedpoly(amidoamine) for the removal of $\mathrm{Cu}^{2+}$ ions from aqueous solution. J Membr Sci 448:125-134

Yu JG, Zhao XH, Yu LY, Jiao FP, Jiang JH, Chen X (2014) Removal, recovery and enrichment of metals from aqueous solutions using carbon nanotubes. J Radioanal Nucl Chem. https://doi. org/10.1007/s10967-013-2818-y

Yun NK, Kwak HW, Lee MG, Lee SK, Lee KH (2014) Electrospun zein nanofibrous membrane for chromium(VI) adsorption. Text Sci Eng 51(2):57-62 
Yunus IS, Harwin A Kurniawan, Adityawarman D, Indarto A (2012) Nanotechnologies in water and air pollution treatment. Environ Technol Rev 1(1):136-148

Yurekli Y (2016) Removal of heavy metals in wastewater by using zeolite nano-particles impregnated polysulfone membranes. J Hazard Mater 309:53-64

Zamzow MJ, Eichbaum BR, Sandgran KR, Shanks DE (1990) Removal of heavy metals and other cations from wastewater using zeolites. Sep Sci Tech 25:1555-1569

Zanin E, Scapinello J, Oliveira M, Rambo CL, Franscescon F, Freitas L, Mello JMM, Fiori MA, Oliveira JV, Dal J (2017) Adsorption of heavy metals from wastewater graphic industry using clinoptilolite zeolite as adsorbent. Process Saf Environ Prot 105:194-200

Zare-Dorabei R, Ferdowsi SM, Barzin A, Tadjarodi A (2016) Highly efficient simultaneous ultrasonic-assisted adsorption of $\mathrm{Pb}(\mathrm{II})$, $\mathrm{Cd}(\mathrm{II}), \mathrm{Ni}(\mathrm{II})$ and $\mathrm{Cu}(\mathrm{II})$ ions from aqueous solutions by graphene oxide modified with 2,2'-dipyridylamine: central composite design optimization. Ultrason Sonochem 32:265-276

Zhang L, Zhou J, Zhou D, Tang Y (1999) Adsorption of cadmium and strontium on cellulose/alginic acid ion-exchange membrane. J Membr Sci 162:103-109

Zhang YP, Wang X, Liu JS, Wu LL (2013) Removal of copper $\left(\mathrm{Cu}^{2+}\right)$ from water using novel hybrid adsorbents: kinetics and isotherms. J Chem Eng Data 58:1141-1150

Zhang H, Yu X, Chen L, Jing Y, Ge Z (2010) Study of 63Ni adsorption on NKF-6 zeolite. J Environ Radioact 101(12):061-1069
Zhao G, Li J, Ren X, Chen C, Wang X (2011) Few-layered graphene oxide nanosheets as superior sorbents for heavy metal ion pollution management. Environ Sci Technol 45(24):10454-10462

Zheng G, Ye H, Zhang Y, Li H, Lin L, Ding X (2014) Removal of heavy metal in drinking water resource with cation-exchange resins (Type 110-H) mixed PES membrane adsorbents. J Hazard Toxic Radioact Waste 19(2):1-6

Zhu W, Liu J, Li M (2014) Fundamental studies of novel zwitterionic hybrid membranes: kinetic model and mechanism insights into strontium removal. Sci World J 2014(2014):7. https://doi. org/10.1155/2014/485820. (Article ID 485820)

Zhu Y, Hu J, Wang J (2014b) Removal of $\mathrm{Co}^{2+}$ from radioactive wastewater by polyvinyl alcohol PVA/chitosan magnetic composite. Prog Nucl Energy 71:172-178

Zhu X, Cui Y, Chang X, Wang H (2016) Selective solid-phase extraction and analysis of trace-level $\mathrm{Cr}(\mathrm{III}), \mathrm{Fe}(\mathrm{III}), \mathrm{Pb}(\mathrm{II})$, and $\mathrm{Mn}$ (II) ions in wastewater using diethylenetriamine-functionalized carbon nanotubes dispersed in graphene oxide colloids. Talanta 146:358-363

Publisher's Note Springer nature remains neutral with regard to jurisdictional claims in published maps and institutional affiliations. 